\title{
Industrial Processes Management for a Sustainable Society: Global Research Analysis
}

\author{
Emilio Abad-Segura ${ }^{1}\left(\mathbb{D}\right.$, Manuel E. Morales ${ }^{2,3}{ }^{\circledR}$, Francisco Joaquín Cortés-García ${ }^{4}$ and \\ Luis Jesús Belmonte-Ureña 1,2,*(D) \\ 1 Department of Economics and Business, University of Almeria, 04120 Almeria, Spain; eas297@ual.es \\ 2 European Center of Biotechnology and Bioeconomy, 3 Rue des Rouges-Terres, 51110 Pomacle, France \\ 3 NEOMA BS, Campus Reims, 59 Rue Pierre Taittinger, 51100 Reims, France; manuel.morales@neoma-bs.fr \\ 4 Faculty of Business and Management, Universidad Autónoma de Chile, 7500912 Santiago, Chile; \\ franciscojoaquincortesgarcia@gmail.com \\ * Correspondence: lbelmont@ual.es
}

Received: 7 May 2020; Accepted: 22 May 2020; Published: 24 May 2020

\begin{abstract}
Few decades ago, the development of the industrial sector was disconnected from society's protection. Negative effects awareness emerges from the current industrial processes through the Sustainable Development Goals (SDGs), considering the causal implications to build up a more sustainable society. The aim of this study is to analyze the state of the art in industrial processes management to obtain positive and sustainable effects on society. Thus, a bibliometric analysis of 1911 articles was set up during the 1988-2019 period, bringing up the authors' productivity indicators in the scientific field, that is, journals, authors, research institutions, and countries. We have identified environmental management; the impact assessments of industrial processes on the environment and its relation with a more sustainable society; as well as the study of the sustainable management of water resources as the related axes in the study of environmental protection with political, economic, and educational approaches. The growing trend of world scientific publications let us observe the relevance of industrial processes management in the implementation of efficient models to achieve sustainable societies. This research contributes to the academic, scientific, and social debate on decision-making both in public and private institutions, and in multidisciplinary groups.
\end{abstract}

Keywords: sustainable process; industry; green technology; effective management; sustainable society; scientific research

\section{Introduction}

Currently, the industrial processes used by responsible and competitive firms must incorporate design efficiency steps. Hence, the sustainability concept is engaged in a process where we can get better indicators with fewer resources [1,2].

In this context, these processes have to support sustainable development, guaranteeing the basic needs of the population, through the rational management of natural resources, and without compromising the sustainability of future societies. Indeed, industrial processes are considered sustainable when they are innovative and compose safety and waste management [3]. Therefore, a society will be sustainable if it is organized in such a way that can guarantee the citizens' and ecosystems' life, through generations [4].

In the overall process, it is necessary to understand that a change from a consumer society to a sustainable conservative society must focus on the wellbeing of the planet and on guarantying future generations. This can only be achieved through the respect of biophysical boundaries and the reduction 
in resources exploitation, which in turn is supposed to encourage social justice from the per capita consumption point of view [5].

Initiatives are supposed to raise awareness about the creation of a more sustainable society that encompasses the Sustainable Development Goals (SDGs) [6,7]. A sustainable society will provide a higher level of well-being in the environment, social and economic dimensions.

With the industrial revolution, global production has been one of the main economic activities of society, triggering a negative impact on the environment. On the other hand, human activity has brought environmental awareness in the median and the political and social agenda around the world $[8,9]$. Sustainability in this study refers to the reduction of negative impacts on environmental, social, and economic relations, in order to approach climate change, pollution, and resources' management [10-12].

The motivation of this study, well justified in the research, is the evolution of the knowledge base of the management of industrial processes with the firm intention of contributing to a society under a model that includes the dimensions of sustainability: environmental, economic, and social.

In the literature review, we have found enough material to answer the research questions defined in this study: (i) what is the knowledge structure of the industrial processes for a sustainable society; (ii) what are the most productive authors, institutions, and countries and; (iii) what are the current research axes in the field and the further perspectives.

Thereby, the aim of this study is the analysis of the current state of the art in management of industrial processes to increase sustainability during the 1988-2019 period.

We identified a sample of 1911 articles from scientific journals in the Scopus database from Elsevier to answer the research questions defined in our study. This study uses the bibliometric method to synthesize the current available knowledge on the management of industrial processes for a sustainable society, from the first article appearance in Scopus (1988) to the last year (2019).

The scientific production in the research field let us identify the main drivers, their current and potential trends, and the gaps in critical knowledge.

The main limit found in this study is the impossibility to know if the number of publications obey the community regulation issues, the demands of interest groups, or the needs required by a global society.

Finally, a set of research axes dedicated to the environmental protection with political, economic, and educational approaches are currently being explored to address environmental management concerns; the impact of industrial processes on the environment and their relationship with a more sustainable society; and the sustainable management of water resources and their effects on society. Therefore, we can conclude that industrial processes are implementing efficient and accountable models, giving rise to sustainability enhancement on society.

\section{Research Scope}

Once the research topic is identified, this section frames the conceptual background within some theoretical principles, and provides the definition used in the study, in order to avoid misinterpretations. Hence, it works as a guideline for the research and provides a framework for outcomes interpretation.

\subsection{Backgrounds}

The Industrial Revolution was the economic, social, and technological starting point; it began in the second half of the 18th century in the United Kingdom, and a few decades after spread to parts of western Europe and North America. In this period, the socioeconomic paradigm evolved from a rural economy, based mainly on agriculture and trade, to an urban, industrialized, and mechanized economy [13-15].

Therefore, the Industrial Revolution was a turning point in history, where both agricultural and industrial production grew exponentially, while reducing production time. 
In the pre-industrial economy, most of the population subsisted thanks to agricultural work, mainly based on self-consumption, trade representing a small percentage of the economy, since productivity was low [16]. Furthermore, cities were small and barely developed, and absolutist monarchies were the government regimes that supported these pre-industrial societies.

The industrial economy triggered technological, socioeconomic, and cultural changes, affecting all structures of society. Overall, scholars addressing technological changes considered the use of new materials, energy sources, and machines, the ones addressing cultural ones inferred an increase in knowledge in the scientific, technical, and health areas, while the social scholars refer to population growth, especially in urban settings [17-19].

Technology currently holds a crosscutting impact on all sectors of the economy and society. The speed of changes is breeding a new industrial revolution, which pushes companies to rethink business models and the sustainability of their processes [20,21].

\subsection{Framework}

A series of theoretical principles, encompassing the industrial processes framework for a sustainable society, support this study. Once the literature review is completed, Table 1 presents the articles that support the main research objectives.

Table 1. Main articles reviewed in relation to the objective of the research topic.

\begin{tabular}{|c|c|c|c|}
\hline Year & Article Title [Reference] & Journal & Author(s) \\
\hline 2019 & $\begin{array}{l}\text { Does corporate social responsibility affect the cost of } \\
\text { equity in controversial industry sectors? [22] }\end{array}$ & $\begin{array}{l}\text { Review of Accounting and } \\
\text { Finance }\end{array}$ & $\begin{array}{l}\text { Hmaittane, A.; } \\
\text { Bouslah, K.; } \\
\text { M'Zali, B. }\end{array}$ \\
\hline 2018 & $\begin{array}{l}\text { UN sustainable development goals: How can } \\
\text { sustainable/green chemistry contribute? The view } \\
\text { from the agrochemical industry [23] }\end{array}$ & $\begin{array}{l}\text { Current Opinion in Green } \\
\text { and Sustainable Chemistry }\end{array}$ & O'Riordan, T.J.C. \\
\hline 2015 & Sustainable Development Titanium Industry [24] & Economy in the Industry & Kostygova, L.A. \\
\hline 2014 & $\begin{array}{l}\text { Green Process Engineering as the Key to Future } \\
\text { Processes [25] }\end{array}$ & Processes & $\begin{array}{l}\text { Patel, D.; Kellici, S.; } \\
\text { Saha, B. }\end{array}$ \\
\hline 2012 & $\begin{array}{l}\text { Controversial issues in factors determining } \\
\text { intra-industry trade [26] }\end{array}$ & $\begin{array}{l}\text { International Journal of } \\
\text { Economics and Business } \\
\text { Research }\end{array}$ & Ferto, I.; Soós, K.A. \\
\hline 2012 & $\begin{array}{l}\text { An Overview of Cement production: How "green" } \\
\text { and sustainable is the industry? [27] }\end{array}$ & $\begin{array}{c}\text { Environmental } \\
\text { Management and } \\
\text { Sustainable Development, }\end{array}$ & Potgieter, J.H. \\
\hline 2006 & $\begin{array}{l}\text { Where is developing country industry in sustainable } \\
\text { development planning? [28] }\end{array}$ & Sustainable Development & Luken, R.A. \\
\hline 2004 & Striving for process excellence [process industry] [29] & Manufacturing Engineer & Venables, M. \\
\hline 1999 & Sustainable development for industry and society [30] & $\begin{array}{l}\text { Building Research } \mathcal{E} \\
\text { Information }\end{array}$ & Stigson, B. \\
\hline 1995 & Green materials and green processes [31] & $\begin{array}{l}\text { Journal of Materials } \\
\text { Research }\end{array}$ & $\begin{array}{l}\text { Szekely, J.; } \\
\text { Laudise, R. }\end{array}$ \\
\hline
\end{tabular}

The industrial processes addressing the achievement of more efficient societies are sustained by the organizational theory, which provides the basis for insertion in the organizations. From the literature review, the theoretical framework of the impact of industrial processes on the environmental, economic, and social dimensions of societies is established.

The stakeholders' theory appears for the first time in a study published by Freeman in 1984, suggesting the change in the company's business models integrating the corporate social responsibility (CSR) concept. Although, the initial aim of these changes was in the environmental dimension, organizations have also showed interest in how to interact with stakeholders [32-35]. Therefore, the increased need to discover how to encourage corporate social responsibility matches the increasing social demands for the business sector to take responsibility for its social impacts and look after the firms' interests $[36,37]$. 
In this study, industry is considered as a set of operations carried out in order to obtain, transform, or transport products encompassed in the secondary sector. The secondary sector is based on the transformation of raw materials into products for intermediate or final consumption, so the industry understanding implies a production process, which will use a certain amount of labor and capital [38,39].

Moreover, industrial firms require resources that, even if not participating directly in the industrial process, make possible to obtain merchandises, which may be for final consumption, if they go straight to consumers, or intermediate goods, if they must cross through another industrial transformation before to be send to consumers.

We consider a process to be a sequence of steps logically arranged with specific aims, i.e., in a firm, a process refers to actions looking for higher efficiency in production, triggering an increase in its profitability by producing more with lower costs [40-42].

In this study, the industrial process is responsible for obtaining, transforming, or transporting one or more raw materials, in order to shift them into materials or products that satisfy the societal needs maximizing utility $[43,44]$. According to the use of natural resources, work characteristics and flexibility on changes, four kinds of processes can be identified: batch processes, continuous flow, piecework, and mass production [45-47].

The concept of sustainability was established in the Brundtland Report in 1987, to relate environment to development, defined as the possibility to meet the current needs without compromising the necessary resources of the future. Eleven years later, in 1998, the concept of sustainability was encompassed in the triple bottom line, where social, environmental, and economic dimensions are interconnected in the firms' understanding [48-51].

In 2015, the United Nations published the 2030 Agenda for Sustainable Development, with 17 Sustainable Development Goals (SDGs) and 169 targets, to verify the progress on sustainability, regarding the economic, social, and environmental dimensions. Sustainability influences organizations, mainly through the SDGs dissemination $[52,53]$. Thereby, the good practices on firms' sustainability need to be aligned with the SDGs indicators to improve accountability and compare information on their actions. Regarding the efficient management of industrial processes, companies should address to following SDGs: $7^{\text {th }}$ goal: Affordable and clean energy; ${ }^{9^{\text {th }}}$ goal: Industry, innovation and infrastructure; $11^{\text {th }}$ goal: Sustainable cities and communities; $12^{\text {th }}$ goal: Responsible production and consumption; and $17^{\text {th }}$ goal: Partnership for the goals [54-57].

The industrial sector must know the 169 goals and identify which are the activities influenced by each of them, so, we can set specific objectives and indicators with which to measure the progress on each activity, resulting in better communication with society and stakeholders. Indeed, companies act as corporate citizens and they have the commitment to implement sustainability in their value chains, minimizing their environmental impact, achieving economic benefits, and improving society $[58,59]$.

Furthermore, the industrial sector must target beyond the written goals defined in the 2030, because each SDG needs innovative solutions. Therefore, stable, sustainable, and equitable wellbeing and social justice is an essential requirement for facing poverty, although this will not be enough [60-62].

According to the United Nations Educational, Scientific and Cultural Organization (UNESCO), the principles that represent sustainability are interdependence, diversity, human rights, global equity and justice, rights of future generations, conservation, values and decisions about lifestyle, democracy and citizen participation, precautionary principle, and economic vitality. All those principles should be included in sustainability trainings [63-65].

The sustainable process takes into account the success of environmental policies based on functionality, efficiency, and sustainability. Companies with highly effective resources and materials management improve their performance and logistics when prioritizing regional production. Sustainability in management also encourage firms to minimize waste and scrap production and through control and review processes, to choose partner companies that have sustainable certifications and standards joining the socially responsible approach [66]. 
Contributing to the sustainability definition, the UN World Commission on Environment and Development identify that a sustainable society is the one that meets the current needs without compromising the ability of future generations to take care of their own needs [67-69].

In general, society joins sustainability seeking to improve the life quality of citizens, improve autonomy, and move through a common good. Hence, the sustainable principles in society indicate the planetary boundaries and capacity for resources, among which are: (i) conservation: buying durable products, consciously consuming, and recycling; (ii) recycling: use over and over, close loops to save energy, avoid pollution, protect habitats, and conserve resources; (iii) rational use of renewable resources; and (iv) population control, to optimize resources in relation to consumption [70-73].

\subsection{Underlying Terminology}

Other concepts have been identified in order to build an underlying conceptual structure in this thematic area, those concepts entail the basis of knowledge on resource management of industrial processes to contribute positively to a sustainable society.

Thus, the effective management concept integrates efficiency as a fundamental term in management systems, measuring the level in which we carry out activities and we achieve successful results according to the plans; how do we manage the interconnected functions to create a corporate policy, in addition to organizing, planning, controlling, and steering the organization's resources in order to achieve their objectives. In this sense, an organization must act effectively, understood as the achievement of results in accordance to the guiding plans [74,75]. We have tools to support organizations in achieving efficiency management of their activities, i.e., systems' management laying on the bases for effective management [76].

On the other hand, the term green technology, also known as green computing, or green IT, refers to the efficient use of computing resources, minimizing the environmental impact, maximizing their economic viability, and ensuring social responsibilities. This set of methods reduces the IT impact on the environment $[77,78]$.

Green-tech protocols must affect practically everything from food to clothing, furniture, cleaning products, packaging, etc. Those protocols represent the only way in which we can expect a reduction or even the elimination of hazardous materials and dangerous habits for society and for the planet [79-81].

The eco-technologies group is composed by the techniques, raw materials, and production systems supported by a non-stop research work. Innovation allows the accomplishment of objectives that transform people's lives on a global scale, based on: (i) circular economy: use of resources, manufacturing-production, consumption, waste, and recycling; (ii) decrease: modify the way of consuming, reducing waste, the amount of energy used and pollution; and (iii) sustainability: finding a way to meet current needs without putting the resources of future generations at risk [82-86].

Furthermore, contributing to the framework of this research, the ISO 2600 assists companies and organizations engaged in a socially responsible operation, clarifying what social responsibility means and helps in the translation of principles into effective actions. The theoretical framework states that companies integrating respect of society and the environment recognize it as a critical success factor and move towards the sustainability assessment in particular and the overall performance in general [87-89].

\section{Materials and Methods}

Bibliometric analysis applies mathematical and statistical methods to scientific literature, with the aim of studying and analyzing scientific activity. The instruments used to measure the scientific activity are the bibliometric indicators that provide information on the scientific activity outcomes. Garfield introduced the bibliometric analysis in the mid-20th century; this method has been widespread in scientific research, for decades contributing to the revision, summary, and analysis of the state of the art across multiple disciplines [90-92]. Thereby, bibliometric analysis has evolved based on the critical thinking of sciences and the availability of scientific databases for researchers. 
The aim of this study is to provide an outlook of the research dynamics of industrial process management to achieve a more sustainable society. We performed a quantitative bibliometric analysis to identify, organize, and analyze trends in the research topic. In recent decades, the bibliometric analysis has contributed to the revision of scientific knowledge and has been used successfully in different scientific fields [93-96].

In the Scopus database, we used a search query using the terms "sustainability", "management", "process", and "industry" to examine the subfields of the title, abstract, and keywords, in a 32 years period, from 1988 to 2019, as shown in other bibliometric works [97,98]. The analyzed period gathered the articles from the first article collected in the Scopus (1988) to the last full year (2019).

We got the sample of the analyzed articles through a search in April 2020. This search only included scientific articles, both in open and non-open access. Hence, the final sample included 1911 documents. The analyzed variables were the year of publication, journal, author, country of affiliation of the author, research institution where the author is affiliated, subject area, and keywords. In this study, the indicators of the analyzed scientific production were the distribution by years of the published articles, and the productivity of the authors, countries, and research institutions. In this sense, Figure 1 shows a diagram with the steps applied in research on industrial process management for a more sustainable society.

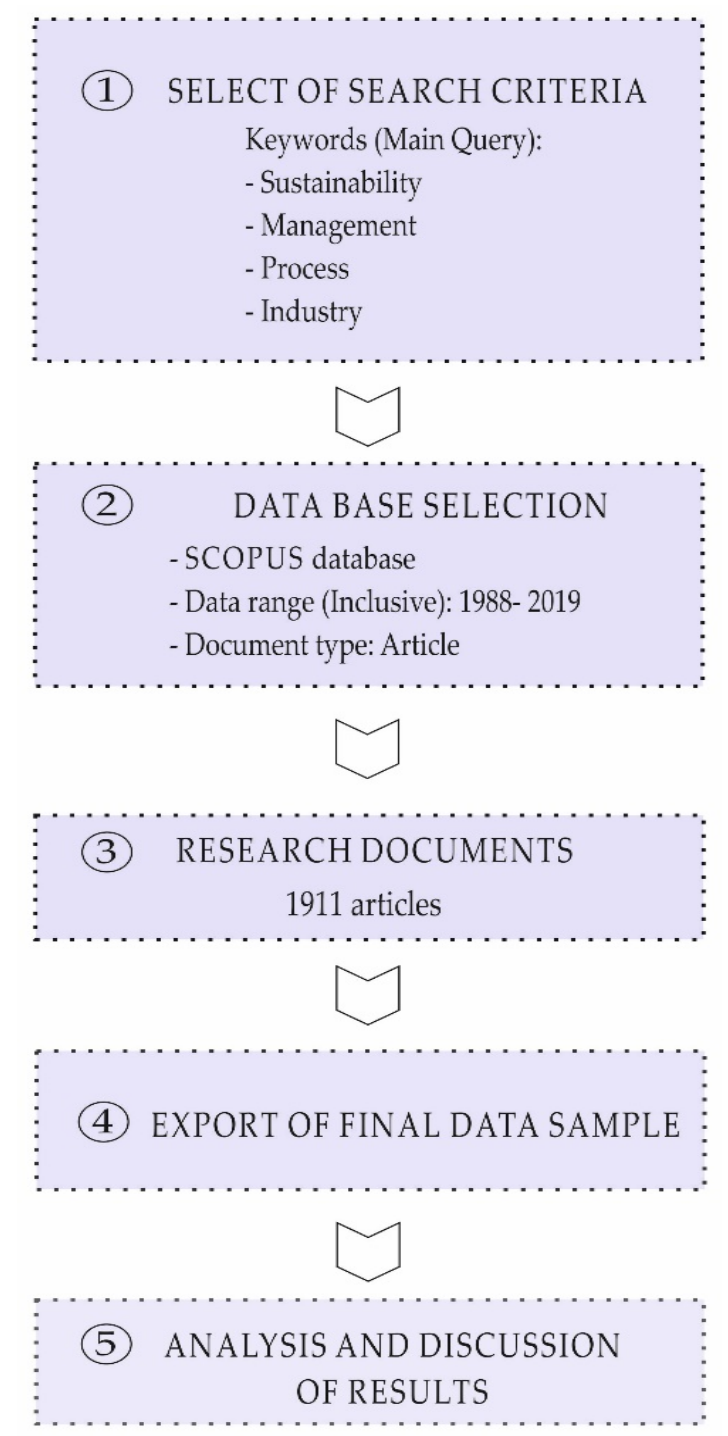

Figure 1. Flowchart of the methodology. 
The quality indicators referring to the impact of the different agents used in this study were: the h-index, which allows detecting the most outstanding authors in the discipline, based on the number of citations received from their articles; citations' number; and the indicator that measures the quality of the scientific journals included in the Scopus database, the 2018 SCImago Journal Rank (SJR) [99-101].

The network indicators, which measure the collaborative links between authors, institutions, and countries, are included in the analysis to provide reliability and suitability in bibliometric analysis, using the analysis of co-authorship. Co-authorship of a technical document is an official declaration of the participation of two or more authors or organizations. Co-authorship analysis is widely used to understand and evaluate patterns of scientific collaboration. In co-authoring networks, nodes represent authors, organizations, or countries, who are connected when they share the authorship of an article.

The keywords analysis in our research topic has allowed the uncovering of the main issues or further perspectives of research topics or problems, based on the analysis of co-occurrences, since scientific articles can be reduced to a set of word appearances. With the analysis of co-occurrences, the proximity relationship of two or more terms in a text unit is established. The co-occurrence of two concepts is very high if they frequently appear together in one set of documents and rarely do so separately in the rest. Furthermore, the graphic representation of the co-occurrence networks allows them to be viewed [102-104].

We have used the software tool VOSviewer (version 1.6.10., Leiden University, Leiden, The Netherlands) for the analysis of these network indicators, which provides data about the interactions and contents assessments, in order to measure the activities of research networks [105,106].

The results obtained are worthy for scholars, practitioners, decision-makers, public authorities, and other stakeholders, because we are assessing the scientific production of a research field with strong influence over society.

\section{Results and Discussion}

\subsection{Analysis of Scientific Production}

The following subsection displays the main characteristics of scientific production, the evolution in the number of articles, and percentages of variation between periods, and, finally, the total number of journals where articles on this topic were published.

Hence, Table 2 shows the evolution of the main characteristics of the articles published on industrial processes for a sustainable society, from 1988 to 2019. The time horizon of the study is 32 years and it has been divided into four-year periods, in order to facilitate the analysis. In this time horizon, interest on the relationship between industrial processes and a sustainable model of society has increased, especially in the last eight years, as observed in the collected data.

Therefore, if in the first period (1988-1991) only 2 articles were published on this topic, in the last four-year period analyzed (2016-2019), the number attempt 845, that is, practically 425 times more. The number of publications increases in the last four-year period, where $44.20 \%$ of the total articles analyzed have been published. This exponential growth could be due to the initiative promoted by the United Nations in 2015, in addition to the definition of the 2030 Agenda and the Millennium Development Goals (MDGs), which propelled collaboration and the progressive increase in scientific publications $[107,108]$. During the last 8 years $(2012-2019), 70 \%$ of the articles have been published (1339), and 2019 was the year with more publications, 271 articles.

On the other hand, the authors Buckley, Pass, and Prescott published in 1988 the first article on the research topic of management of industrial processes for a sustainable society, with the title "Measures of international competitiveness: A critical survey", in the Journal of Marketing Management. This article is classified in the "Business, Management, and Accounting" thematic area [109]. Likewise, it should be noted that the same article can be classified in more than one category, which will depend on the publisher and author. 
Table 2. Main characteristics of scientific production (1998-2019).

\begin{tabular}{ccccccc}
\hline Period & A & AU & C & TC & TC/A & J \\
\hline $1988-1991$ & 2 & 4 & 2 & 205 & 102.5 & 2 \\
$1992-1995$ & 2 & 4 & 1 & 63 & 31.5 & 2 \\
$1996-1999$ & 38 & 73 & 13 & 764 & 20.1 & 35 \\
$2000-2003$ & 84 & 224 & 34 & 2716 & 32.3 & 73 \\
$2004-2007$ & 135 & 345 & 42 & 3415 & 25.3 & 105 \\
$2008-2011$ & 311 & 879 & 53 & 11,919 & 38.3 & 226 \\
$2012-2015$ & 494 & 1553 & 70 & 11,339 & 23.0 & 315 \\
$2016-2019$ & 845 & 2813 & 82 & 5299 & 6.3 & 386
\end{tabular}

A: number of articles; AU: number of authors; C: number of countries; TC: number of citations in total articles; TC/A: number of citations per article; J: number of journals.

Figure 2 shows the evolution in the number of articles and the variation percentage between each four-year period studied. In addition, we highlight the increase percentage between the second and third periods analyzed (1800\%), in 1992-1995 and 1996-1999, even at that time the scientific activity in this field of study was still very low. The percentage increase in the number of publications in the 2008-2011 period $(130.40 \%)$, obey to the fact that it is the first four-year period with more than 300 articles (311).

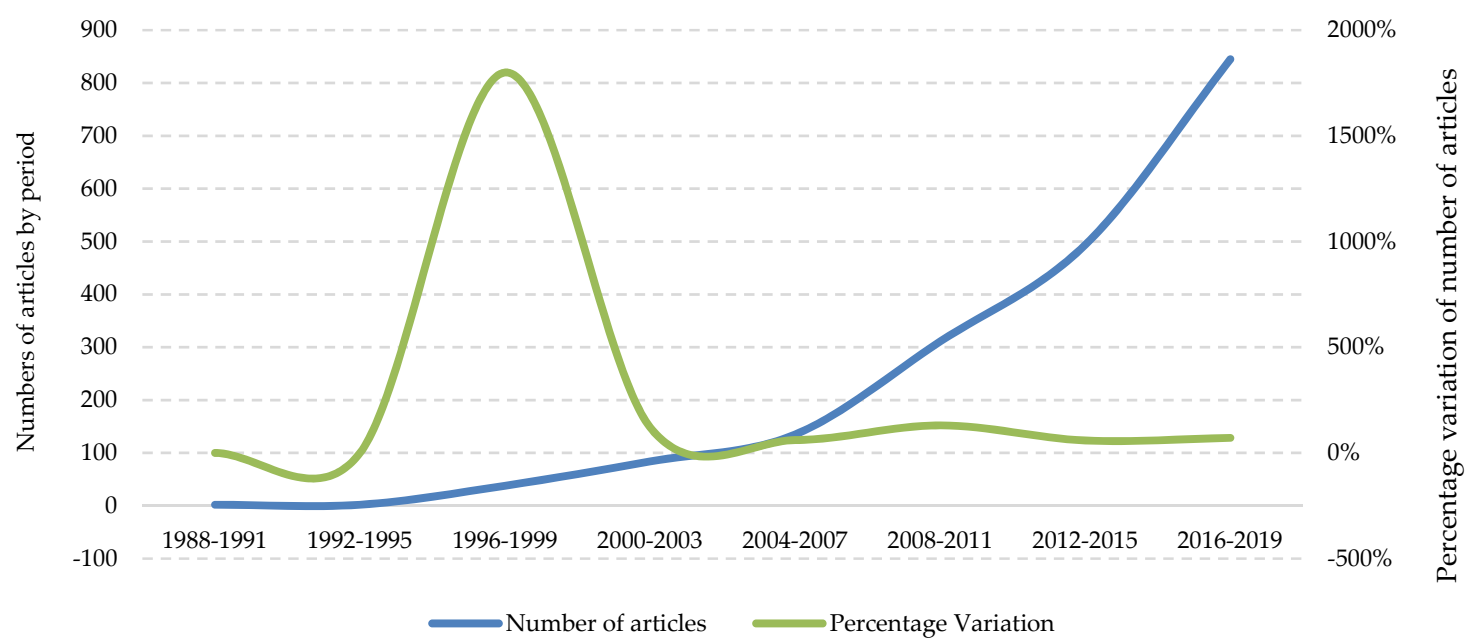

Figure 2. Evolution of the number of articles and percentage of variation between four-year periods.

The total amount of authors who have contributed to this research topic during the analyzed period was 5895. The total number of authors has also increased during this period, as does the volume of articles. In the last three years (2016-2019), 47.70\% of the total amount of authors from the 32-year period is concentrated. In addition, we observe that the number of authors who published on the relationship between industrial processes and a sustainable society in the first period (1988-1991) was 4, increasing to 2813 between 2016-2019. The number of authors experience a higher increase than the number of published articles, because in the recent years, the average number of authors per article has also increased. In the four-year period 1988-1991, the average number of authors per article was 2 authors per article, while in the last period (2016-2019) it increased to 3.3, the highest average of authors per article in the studied time horizon.

In the analyzed period (1988-2018), the total number of countries that has at least one pubblication is 99. Thereby, the number of countries has increased from two in the first period (1988-1991) to 82 in the last one (2016-2019).

We account 205 citations for the 2 articles published between 1988-1991, then the number of citations grew exponentially, from the second period (1992-1995), with 63, to the sixth four-year period 
analyzed (2008-2011), with 11,919. Since 2011, the total number of citations decreased, as showed by the 2012-2015 and 2016-2019 periods, with 11,339 and 5229, respectively. The circumstance of the decrease in the number of citations is due to the fact that the most recent articles published will receive more citations in the coming years [110]. The decreasing in the overall number of citations is also related to the decreasing in the average number of citations per article, because it has decreased from the first four-year period (2001-2003), with 102.5, to the last period (2016-2018), with 6.3.

Finally, the total number of journals where "Industrial process management for a sustainable society" topics were published has been 864 throughout the 32 years period. Thus, the journals incidence increased from 2 in the first observed period to 386 in the last period (2016-2019), which represents $44.7 \%$ of the total.

\subsection{Distribution of Publications by Subject Area and Journal}

The following Section 4.2 displays the main thematic areas related to scientific production. Likewise, a comparison of growth trends according to the main thematic areas is presented and a ranking of the most prolific journals on this subject is shown.

During the analyzed timeframe, 1988-2019, we found 26 categories according to the Scopus classification, with studies related to industrial processes and sustainable society. We classified the sample of 1911 articles in the 26 subject areas, an article can be classified in more than one subject area, depending on the author and editor's interest.

Figure 3 presents the evolution over time of the 5 main themes, through the Scopus analytics that links articles of the sample (1988-2019) with the underpinning subject areas.

The most studied category throughout the studied period is "Environmental Science", with 22\% of published articles (914) in this category. Followed, by "Business, Management, and Accounting" (14\%, 583), "Engineering" (14\%, 583), "Social Sciences" (11\%, 467), and "Energy" (9\%, 373) categories in order of importance. Therefore, the previous five categories represent $71 \%$ of the documents published from 1988 to 2019. The rest of the subject area categories do not exceed 3\% of total articles published except for "Agricultural and Biological Sciences" (5.2\%, 214), and "Economics, Econometrics, and Finance" $(4 \%, 172)$.

Environmental Science, with an exponential growth, is the only subject area that published articles in all the analyzed periods, followed by Business, Management, and Accounting that almost published in all periods, except in 1992-1995.

The shared features identified in the "Environmental Science", "Business, Management, and Accounting" and "Engineering and Social Sciences" publications categories, is that the research topics are linked both conceptually and practically to management, technological processes, and the dynamics of industrialization, environmental impact, environmental sustainability, and the socio-economic systems that encompass the biophysical boundaries. Hence, it is recognized by authors who relate the impact of environmental and organizational practices of industries to business [111,112]. 


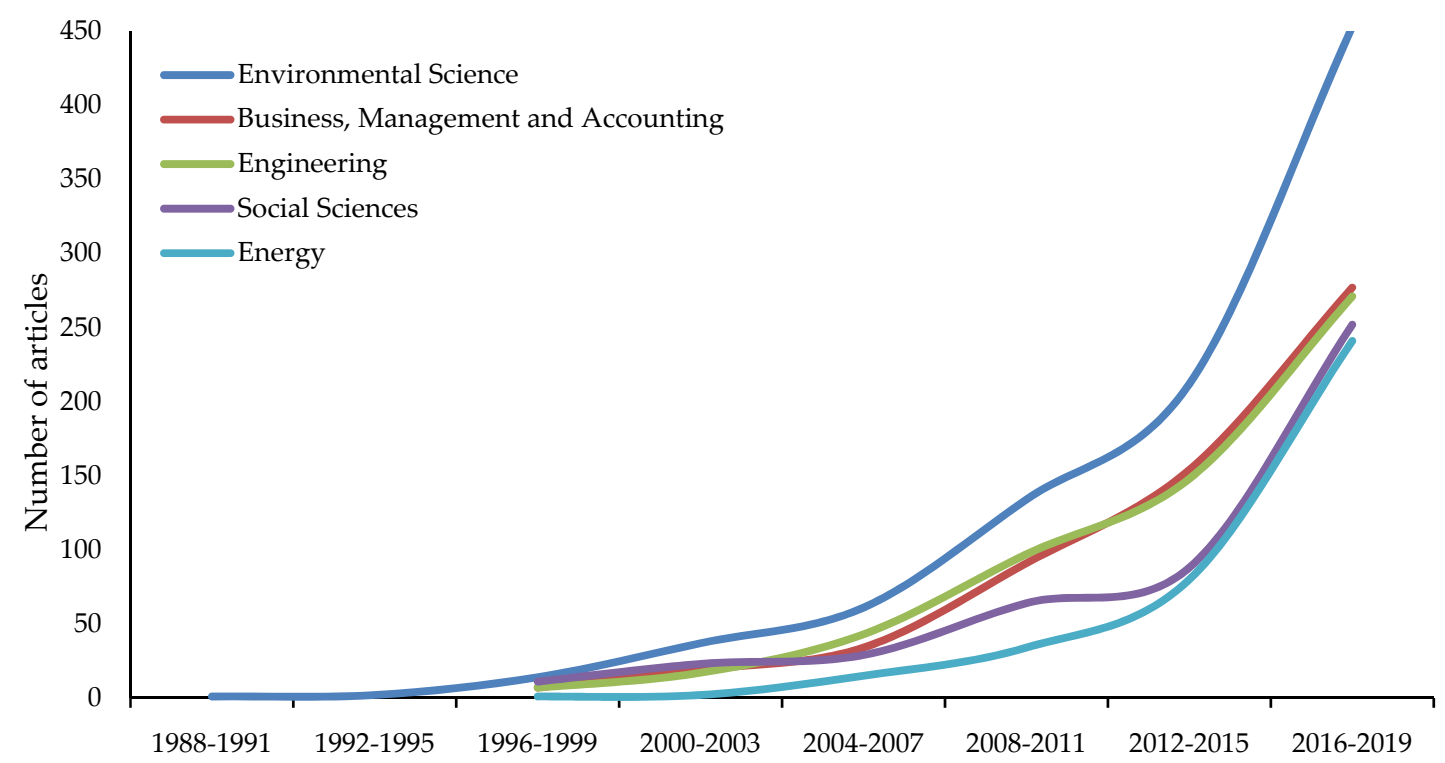

Figure 3. Comparison of growth trends of main subject areas (1988-2019).

Table 3 shows the characteristics of articles in the overall investigation of industrial processes for a sustainable society. We rank the 20 journals with most articles published, the journals belonging to the first quartile (Q1) of the 2018 SJR index stands out with $75 \%$ of total articles. In addition, the International Journal of Production Economics, has the highest impact factor, SJR, with 2.475 (Q1), followed by Business Strategy and the Environment journal, with 2.166 (Q1).

The Journal of Cleaner Production $(137,7.17 \%)$ and Sustainability $(111,5.81 \%)$ are the two journals that have published the most articles. The top 20 journals in this research has published $29.20 \%(558)$ of all articles. On the other hand, the Journal of Cleaner Production is the journal that has the most in the first position of the ranking, with 3 out of 8 periods analyzed, even when the Sustainability (99) journal attains the first position, with the highest number published articles, in the last period of the analysis (2016-2019). Furthermore, the Journal of Cleaner Production is well-recognized by the scientific community, standing out as the most cited per period (4142), although the International Journal of Production Economics holds the highest average of citations per article (185.22) per period and the highest h-index for published articles (38), followed by Resources Conservation and Recycling (18) in the second place, while the highest h-index for all subjects is presented by Science of the Total Environment (205).

We notice that the herein analyzed research has increased in the number of journals and authors over the years, as evidenced by the increase in the indicators of number of articles and journals $[113,114]$. The European origin journals stand out as the most relevant: the United Kingdom (8), Netherlands (4), Switzerland (1), Germany (1), and Italy (1); and the American ones (5). 
Table 3. Top 20 prolific journals (1998-2019).

\begin{tabular}{|c|c|c|c|c|c|c|c|c|c|c|c|c|c|c|c|}
\hline \multirow{2}{*}{ Journal } & \multirow{2}{*}{ A } & \multirow{2}{*}{ TC } & \multirow{2}{*}{ TC/A } & \multirow{2}{*}{ Ha } & \multirow{2}{*}{$\mathbf{H j}$} & \multirow{2}{*}{$\operatorname{SJR}(Q)$} & \multirow{2}{*}{ Country } & \multicolumn{8}{|c|}{ R (A) } \\
\hline & & & & & & & & $88-91$ & $92-95$ & 96-99 & 00-03 & 04-07 & 08-11 & $12-15$ & 16-19 \\
\hline Journal of Cleaner Production & 137 & 4142 & 30.23 & 38 & 150 & $1.620(\mathrm{Q} 1)$ & Netherlands & 0 & 0 & 0 & 0 & 1(6) & $1(8)$ & 1(33) & $2(90)$ \\
\hline Sustainability (Switzerland) & 111 & 609 & 5.49 & 15 & 53 & $0.549(\mathrm{Q} 2)$ & Switzerland & 0 & 0 & 0 & 0 & 0 & 0 & 2(12) & 1(99) \\
\hline $\begin{array}{c}\text { Journal of Environmental } \\
\text { Management }\end{array}$ & 31 & 564 & 18.19 & 13 & 146 & $1.206(\mathrm{Q} 1)$ & USA & 0 & 0 & 0 & $7(2)$ & $70(1)$ & $3(6)$ & $7(7)$ & $5(15)$ \\
\hline $\begin{array}{c}\text { Business Strategy and the } \\
\text { Environment }\end{array}$ & 21 & 686 & 32.67 & 11 & 84 & $2.166(\mathrm{Q} 1)$ & USA & 0 & 0 & $8(1)$ & 0 & $5(3)$ & $8(4)$ & 20(3) & $7(10)$ \\
\hline Marine Policy & 21 & 343 & 16.33 & 9 & 79 & 1.242(Q1) & UK & 0 & 0 & 0 & $55(1)$ & $11(2)$ & $38(2)$ & 11(6) & $8(10)$ \\
\hline Waste Management & 18 & 603 & 33.50 & 15 & 127 & $1.523(\mathrm{Q} 1)$ & UK & 0 & 0 & 0 & 0 & 0 & $46(2)$ & $14(5)$ & $6(11)$ \\
\hline $\begin{array}{c}\text { International Journal of Life Cycle } \\
\text { Assessment }\end{array}$ & 16 & 264 & 16.50 & 9 & 89 & $1.538(\mathrm{Q} 1)$ & Germany & 0 & 0 & 0 & 0 & $57(1)$ & $32(2)$ & $9(6)$ & $9(7)$ \\
\hline Journal of Industrial Ecology & 11 & 479 & 43.55 & 9 & 85 & 1.486(Q1) & USA & 0 & 0 & 0 & 0 & 0 & 2(8) & $49(2)$ & 180(1) \\
\hline $\begin{array}{c}\text { Chemical Engineering } \\
\text { Transactions }\end{array}$ & 10 & 30 & 3.00 & 3 & 29 & $0.273(\mathrm{Q} 3)$ & Italy & 0 & 0 & 0 & 0 & 0 & 0 & $15(4)$ & $10(6)$ \\
\hline $\begin{array}{c}\text { Management of Environmental } \\
\text { Quality }\end{array}$ & 10 & 88 & 8.80 & 5 & 29 & $0.358(\mathrm{Q} 3)$ & UK & 0 & 0 & 0 & 0 & $3(4)$ & 135(1) & $27(3)$ & 105(2) \\
\hline Energy & 9 & 309 & 34.33 & 7 & 158 & $2.048(\mathrm{Q} 1)$ & UK & 0 & 0 & 13(1) & 0 & $36(1)$ & 13(3) & $115(1)$ & $36(3)$ \\
\hline $\begin{array}{l}\text { International Journal of } \\
\text { Production Economics }\end{array}$ & 9 & 1667 & 185.22 & 8 & 155 & 2.475(Q1) & Netherlands & 0 & 0 & 0 & 0 & 0 & $130(1)$ & $16(4)$ & $26(4)$ \\
\hline $\begin{array}{l}\text { Journal of Management in } \\
\text { Engineering }\end{array}$ & 8 & 292 & 36.50 & 6 & 55 & $1.271(\mathrm{Q} 1)$ & USA & 0 & 0 & 0 & 0 & $73(1)$ & 0 & $8(7)$ & 0 \\
\hline
\end{tabular}

A: number of articles; R: rank position by number of articles in the four-year period; TC: number of citations; TC/A: number of citations by article; Ha: h-index in articles; Hj: h-index in journal; SJR(Q): Scimago Journal Rank 2018 (Quartile).

In 2008, Vachon and Klassen published the most cited article (848) "Environmental management and manufacturing performance: The role of collaboration in the supply chain" in the International Journal of Production Economics, included into the "Business, Management and Accounting" and "Economics, Econometrics and Finance" subject area categories [115]. This article was the only published article about this topic of analysis in the previous journal during the period (2008-2011).

\subsection{Productivity of Authors, Institutions, and Countries}

Section 4.3 displays the most productive authors and the cooperation between them based on co-authorship. As for the institutions, the most prolific are shown, the countries with the highest production and the network of cooperation among them based on co-authorship, and the most productive international collaborations.

Hence, Table 4 shows what we consider as the most important variables from articles written by the 12 most prolific authors on the topic of management of industrial processes for a sustainable society during the period 1988-2019. It is noteworthy to mention that seven authors in this ranking are European: Germany (3), Italy (2), and the United Kingdom (1), and 2 North Americans: the United States (1), and Canada (1).

The most productive author on the analyzed topic is the German, Seuring, from the Universität Kassel, with seven published articles, followed by the Italians, Colla, from the Scuola superiore di studi universitari e di perfezionamento Sant'Anna, and, Ulgiati, from Parthenope University of Naples, with six published articles each. Regarding citations, the German, Seuring from the Universität Kassel holds the first place with 583 citations, although the authors with the highest average number of citations per article are also Germans, Foerstl and Hartmann, with 107.40 and 103.60, respectively and not the Italians Colla and Ulgiati, accounting six articles each. In addition, Seuring also stands out with the highest h-index (7), followed by Ulgiati (6). All authors in this ranking published their first article from 2000, and seven show interest in this topic in 2019, publishing at least one article. 
Likewise, the main thematic area (Environmental Sciences) associated with the contributions of each of the most productive authors has been identified, reflecting the motivations in this scientific field and the inclinations of the journals for the publication of these lines of research, such as the reviewed literature shows [116,117].

Table 4. Top 12 prolific authors (1988-2019).

\begin{tabular}{|c|c|c|c|c|c|c|c|c|}
\hline Author & A & TC & TC/A & Institution & C & First A & Last $\mathrm{A}$ & h-index \\
\hline Seuring, $\mathrm{S}$. & 7 & 583 & 83.29 & Universität Kassel & Germany & 2003 & 2015 & 7 \\
\hline Colla, V. & 6 & 75 & 12.50 & Scuola Superiore Sant'Anna & Italy & 2014 & 2018 & 5 \\
\hline Ulgiati, S. & 6 & 129 & 21.50 & Parthenope University of Naples & Italy & 2011 & 2019 & 6 \\
\hline Foerstl, K. & 5 & 537 & 107.40 & German Graduate School of Management and Law & Germany & 2010 & 2018 & 5 \\
\hline Genovese, A. & 5 & 334 & 66.80 & Sheffield University Management School & UK & 2015 & 2018 & 5 \\
\hline Govindan, $\mathrm{K}$. & 5 & 168 & 33.60 & Syddansk Universitet & Denmark & 2014 & 2019 & 4 \\
\hline Huisingh, D. & 5 & 360 & 72.00 & The University of Tennessee & USA & 2009 & 2019 & 5 \\
\hline Hussain, M. & 5 & 2 & 0.40 & Abu Dhabi University & United Arab Emirates & 2017 & 2019 & 1 \\
\hline Raut, R.D. & 5 & 21 & 4.20 & National Institute of Industrial Engineering & India & 2015 & 2019 & 3 \\
\hline
\end{tabular}

A: number of articles; TC: number of citations; TC/A: number of citations by article; C: country; First A: First article; Last A: Last article; h-index: Hirsch index in this research topic.

Figure 4 shows the networking map between the main authors that published on the topic industrial processes for a sustainable society, based on the co-authorship analysis. In Figure 4 , the different colors represent the networking clusters of articles production, while the size of the circle changes according to the number of articles published by author. The network shows high dispersion in the authors' collaboration during the analyzed period (1988-2019). This limited collaboration in the network influences the overall evolution of the social structure of this research topic. We note that the limited scientific collaboration between the authors, in some way involves a wide scope in the subject areas, in addition to promoting innovation, and facilitating access to various topics of study in the field of research [118,119].

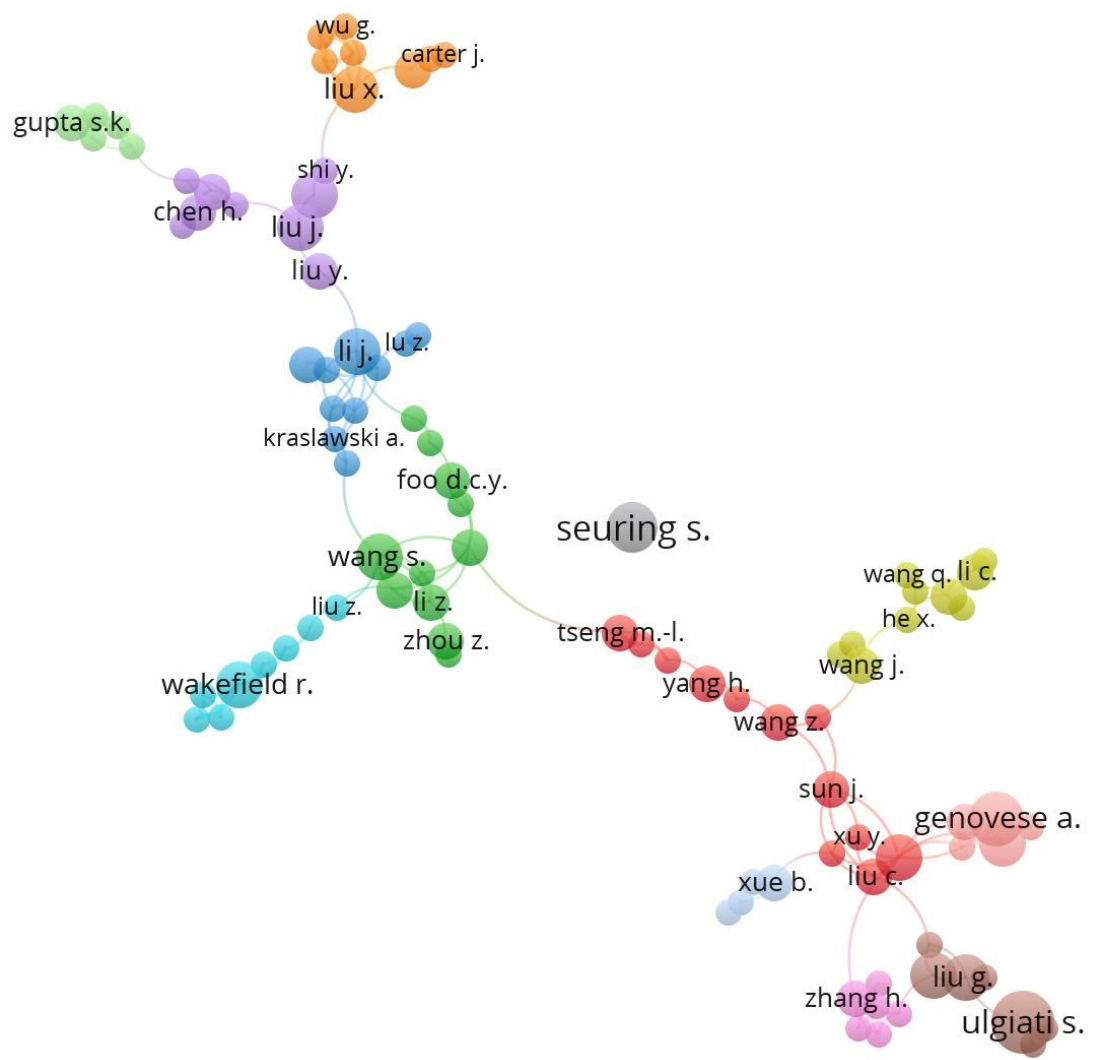

Figure 4. Network map of cooperation between authors based on co-authorship (1988-2019). 
Table 5 shows the 10 institutions with the highest number of published articles during the period of study (1988-2019). We observe that the institutions in the ranking have a diverse origin, for example, $30 \%$ of the institutions are European (Imperial College London, Politecnico di Milano, and Wageningen University and Research Center), 30\% from Asia (Chinese Academy of Sciences, Hong Kong Polytechnic University, and Beijing Normal University), and 20\% from Australia (University of Queensland and University of Melbourne). The Chinese Academy of Sciences is the most productive institution with 21 articles, while the most cited institution (851) with the highest average of citations per article (50.06) is the University of British Columbia (851) from Canada. The University of British Columbia and the Imperial College London share the highest h-index (12) in this research topic.

On the other hand, Hong Kong Polytechnic University is the institution with the highest percentage of international collaboration (64.3\%), although the international collaboration does not influence the number of citations, in comparison with articles written without international co-authorship. The Politecnico di Milano and the Wageningen University and Research Center are the only two institutions where international co-authorship outstands as a profitable practice, because the articles published by these two institutions have a much higher number of international citations.

Table 5. Top 10 prolific institutions (1988-2019).

\begin{tabular}{|c|c|c|c|c|c|c|c|c|}
\hline Institution & $\mathrm{C}$ & A & TC & TC/A & h-index & IC (\%) & TCIC & TCNIC \\
\hline The University of British Columbia & Canada & 17 & 851 & 50.06 & 12 & $41.2 \%$ & 48.86 & 50.90 \\
\hline University of Queensland & Australia & 17 & 440 & 25.88 & 10 & $52.9 \%$ & 29.33 & 22.00 \\
\hline Universidade de Sao Paulo - USP & Brazil & 14 & 241 & 17.21 & 8 & $14.3 \%$ & 14.00 & 17.75 \\
\hline Hong Kong Polytechnic University & Hong Kong & 14 & 565 & 40.36 & 10 & $64.3 \%$ & 25.11 & 67.80 \\
\hline Wageningen University and Research Centre & Netherlands & 13 & 594 & 45.69 & 9 & $61.5 \%$ & 64.25 & 16.00 \\
\hline Beijing Normal University & China & 13 & 124 & 9.54 & 8 & $61.5 \%$ & 10.88 & 7.40 \\
\hline
\end{tabular}

C: country; A: number of articles; TC: number of citations; TC/A: number of citations by article; h-index: Hirsch index in research topic; IC: percentage of articles made with international collaboration; TCIC: number of citations by article made with international collaboration; TCNIC: number of citations by article made without international collaboration.

Table 6 shows the countries with the highest scientific production on industrial processes for a sustainable society, including the ones we consider the most characteristics.

In our study, the United States stands out as the country with most publications (289) and with the highest h-index, along with the United Kingdom (47). In addition, the United States has the highest number of citations (7481), and 32.25 average citations per article, positioning in the second place in the average citation rate, just behind Canada (43.96) with only 95 articles.

The amount of American and English publications stands out in the interest of those countries on the management of industrial processes for a sustainable society. The United States started publishing on the management of industrial processes for a sustainable society in 1996, and it has led the ranking of publication productivity on this topic in all periods, excluding the 2004-2017 period. China has the second position in articles productivity at the last period (2016-2019), with 90 items, representing the $68.2 \%$ of total production. We observe, what we think is a notworthy characteristic in the top 10 ranking of countries articles production, that Italy (2003), Brazil (2003), and Spain (2003), out of 10 countries, published its first article until the fourth period (2000-2003).

In short, the United States, the United Kingdom, Australia, China, and Italy, are the 5 most engaged countries on this research subject, with 50\% (952) of all analyzed articles. This ranking coincides with the countries that produce the most scientific documents, and the excellence rate that includes the most cited articles in their area. The latter is an indicator of the high quality of research in these countries [120,121]. 
Table 6. Top 10 prolific countries in number of articles (1998-2019).

\begin{tabular}{|c|c|c|c|c|c|c|c|c|c|c|c|c|}
\hline \multirow{2}{*}{ Country } & \multirow{2}{*}{$\mathbf{A}$} & \multirow{2}{*}{ TC } & \multirow{2}{*}{ TC/A } & \multirow{2}{*}{ h-index } & \multicolumn{8}{|c|}{ R (A) } \\
\hline & & & & & 1988-1991 & 1992-1995 & 1996-1999 & $2000-2003$ & 2004-2007 & 2008-2011 & 2012-2015 & 2016-2019 \\
\hline USA & 289 & 6828 & 23.63 & 47 & 0 & 0 & $1(9)$ & $1(17)$ & $3(16)$ & $1(62)$ & $1(93)$ & $1(92)$ \\
\hline UK & 232 & 7481 & 32.25 & 47 & $2(1)$ & 0 & $2(8)$ & $3(12)$ & $1(20)$ & $2(50)$ & $3(52)$ & $3(89)$ \\
\hline Australia & 189 & 3760 & 19.89 & 35 & 1(1) & 0 & $5(2)$ & $2(12)$ & 2(19) & $3(43)$ & 2(53) & $5(59)$ \\
\hline China & 132 & 1146 & 8.68 & 20 & 0 & 0 & $9(1)$ & 19(1) & $10(5)$ & $11(8)$ & $7(27)$ & $2(90)$ \\
\hline Italy & 110 & 2236 & 20.33 & 25 & 0 & 0 & 0 & 22(1) & 21(2) & $9(9)$ & $4(42)$ & $7(56)$ \\
\hline Brazil & 107 & 1064 & 9.94 & 19 & 0 & 0 & 0 & $17(1)$ & $9(6)$ & $10(8)$ & $5(36)$ & $6(56)$ \\
\hline Spain & 101 & 2416 & 23.92 & 25 & 0 & 0 & 0 & $31(1)$ & $13(4)$ & $4(18)$ & $8(27)$ & $8(51)$ \\
\hline India & 100 & 1290 & 12.90 & 16 & 0 & 0 & $6(2)$ & $6(4)$ & $11(5)$ & $12(8)$ & $10(20)$ & $4(61)$ \\
\hline Germany & 98 & 2822 & 28.80 & 28 & 0 & 0 & $11(1)$ & $5(6)$ & $4(10)$ & $8(13)$ & $6(29)$ & $11(39)$ \\
\hline Canada & 95 & 4176 & 43.96 & 28 & 0 & 0 & $7(1)$ & $4(7)$ & $6(9)$ & $5(17)$ & $9(20)$ & $10(41)$ \\
\hline
\end{tabular}

A: number of articles; R: rank position by number of articles in the four-year period; TC: number of citations; TC/A: number of citations by article; h-index: Hirsch index in research topic.

Table 6 shows the indicators regarding international collaboration ordered by the amount of scientific production in the observed period (1988-2019). We identify the international networks of scientific collaboration lead by China with $55.3 \%$ (45 countries), followed by Canada $(50.5 \%$, 28$)$, Spain $(45.5 \%, 38)$, and the United Kingdom $(41.4 \%, 45)$. In our ranking, India is the country with the lowest percentage of international collaboration $(17 \%, 8)$.

On the other hand, we observe in Table 7 that the number of articles' citations is higher where international co-authorship is entailed than those made without international collaborations, exception made by the United Kingdom, Germany, and Canada.

Table 7. Top 10 prolific countries and international collaboration (1998-2019).

\begin{tabular}{cccccc}
\hline \multirow{2}{*}{ Country } & \multirow{2}{*}{ NC } & Main Collaborators & \multirow{2}{*}{ IC (\%) } & \multicolumn{2}{c}{ TC/A } \\
\cline { 5 - 6 } & & & IC & NIC \\
\hline USA & 44 & UK, Canada, China, Australia, Germany & $33.6 \%$ & 32.48 & 19.15 \\
UK & 45 & USA, Spain, Germany, Italy, Canada & $41.4 \%$ & 29.72 & 34.03 \\
Australia & 36 & China, UK, USA, Canada, Netherlands & $39.2 \%$ & 22.26 & 18.37 \\
China & 38 & Australia, USA, UK, Hong Kong, Italy & $55.3 \%$ & 9.03 & 8.25 \\
Italy & 30 & UK, Spain, USA, China, Germany & $33.6 \%$ & 33.35 & 13.73 \\
Brazil & 22 & Canada, UK, USA, China, Portugal & $21.5 \%$ & 12.43 & 9.26 \\
Spain & 38 & UK, Italy, Chile, Germany, USA & $45.5 \%$ & 30.57 & 18.36 \\
India & 8 & USA, Denmark, UK, Australia, Canada & $17.0 \%$ & 38.76 & 7.60 \\
Germany & 26 & UK, Switzerland, USA, Austria, Netherlands & $39.8 \%$ & 26.59 & 30.25 \\
Canada & 28 & USA, UK, Australia, Brazil, China & $50.5 \%$ & 27.31 & 60.96 \\
\hline
\end{tabular}

NC: number of collaborator countries; IC: percentage of articles made with international collaboration; TC/A: number of citations by article; IC: international collaboration; NIC: no international collaboration.

Figure 5 shows a networking map between countries based on the co-authorship analysis, where the different colors represent the different clusters build up by the groups of countries, while the size of the circle changes according to the number of articles published by country $[122,123]$. The VOSviewer software identifies eight sets of components.

Cluster 1 is the largest and includes 14 countries, led by Australia with 189 published articles. Cluster 1 is associated with Malaysia (65 articles), Iran (22), Mexico (21), Chile (18), Indonesia (18), Japan (16), Lithuania (11), Saudi Arabia (11), Pakistan (10), Egypt (9), Bangladesh (7), Kenya (6), and Nigeria (6). Cluster 2 has Italy (100) at the head and is associated with Brazil (107), Canada (95), Sweden (52), France (50), Portugal (26), Thailand (21), Norway (16), United Arab Emirates (11), Serbia (10), and Slovenia (7). Cluster 3 is led by Spain (101) and includes Finland (42), Russian Federation (22), Greece (18), New Zealand (18), Romania (14), Poland (13), and Hungary (12). Cluster 4 is leaded by Germany (98), and includes the Netherlands (60), Switzerland (35), Austria (22), Belgium (20), Ireland (17), and Colombia (9). Cluster 5 is leaded by the United States (289) and includes Turkey (38), South Korea (26), Singapore (9), Qatar (6), and Croatia (5). Cluster 6 has China (132) at the head and cooperates with South Africa (47), Taiwan (32), Hong Kong (23), and the Philippines (8). Cluster 7 is 
led by the United Kingdom (232), and collaborates with Czech Republic (8), and Slovakia (7). Finally, cluster 8 is composed by India (100) and Denmark (29).

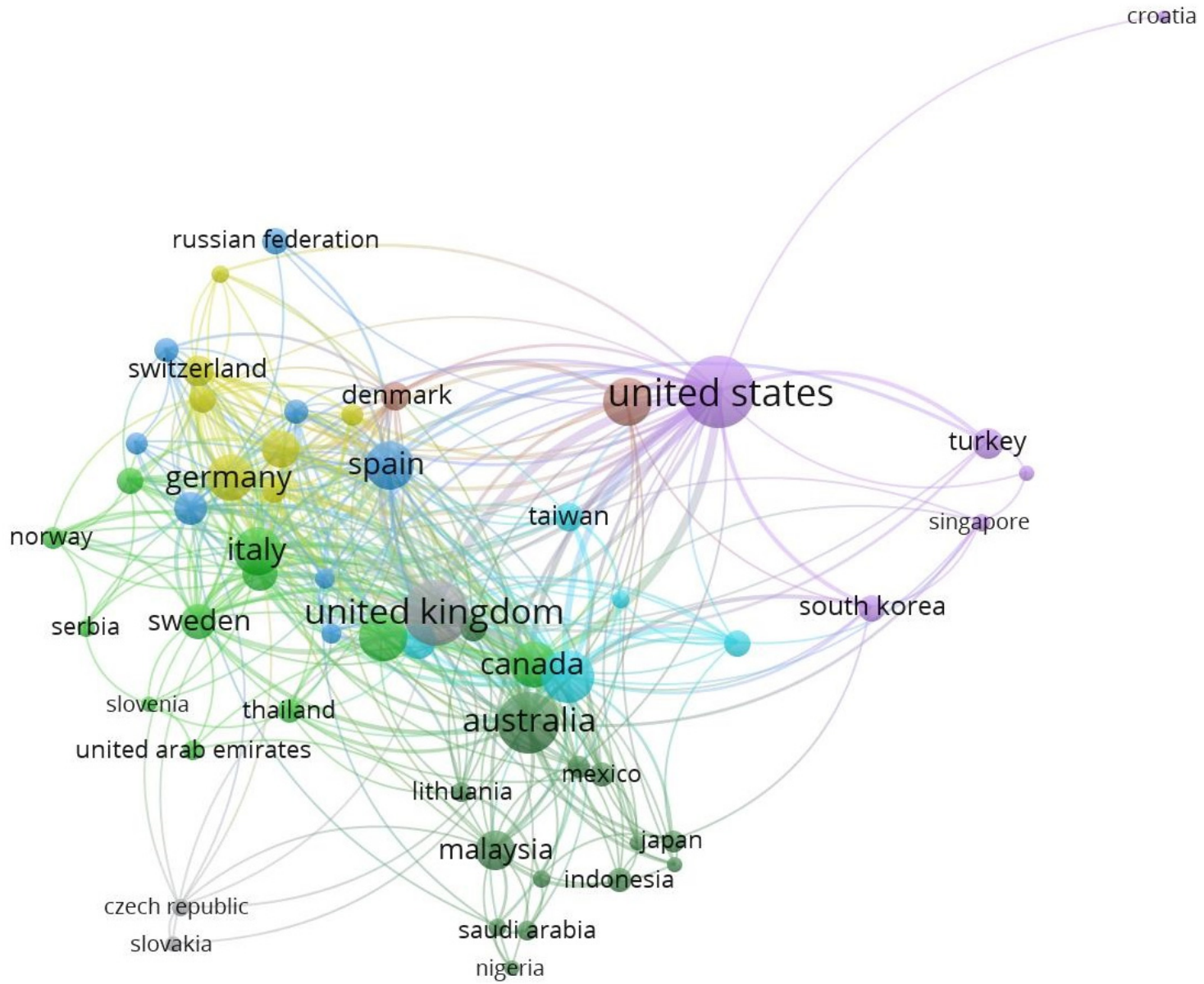

Figure 5. Network of cooperation between countries based on co-authorship (1988-2019).

\subsection{Keywords Analysis}

Section 4.4 displays an analysis of the most relevant keywords, the keyword network map based on co-occurrence and their evolution, during the period analyzed (1988-2019).

Therefore, Table 8 lists the 20 most frequently used keywords in the sample of 1911 articles during the observed period (1988-2019) divided in eight four-year periods within the 32-year timeframe. The most outstanding terms are Sustainability (864 articles, 45.2\%) and Sustainable Development $(757,39.6 \%)$. In the literature review, both terms are considered as synonyms [124], then if we observe them together, they rank first in 6 out of 8 four-year periods (Sustainability: 2000-2003, 2008-2011, 2016-2019; and Sustainable Development: 1996-1999, 2004-2007, 2012-2015). We identify the keywords Environmental Management (262, 13.7\%), Decision Making (235, 12.3\%), and Environmental Impact $(212,11.1 \%)$ listed in order of importance.

Indeed, we identify four thematic axes according to the keywords semantics. Hence, the first group is associated with sustainability in processes (Sustainability, Sustainble Development, Life Cycle, Recycling, and Life Cycle Assessment); the second is related to the environmental dimension of industry (Environmental Management, Environmental Impact, Environmental Sustainability, and Environmental Protection); the third with the management of industrial processes (Decision Making, Waste Management, Supply Chain Management, Water Management, Project Management, Economics, and Stakeholder); and the fourth with the industry itself (Construction Industry, Industry, and Innovation). 
Table 8. Top 20 keywords (1988-2019).

\begin{tabular}{|c|c|c|c|c|c|c|c|c|c|c|c|c|c|c|c|c|c|c|}
\hline \multirow[b]{2}{*}{ Keyword } & \multicolumn{2}{|c|}{ 1988-2019 } & \multicolumn{2}{|c|}{ 1988-1991 } & \multicolumn{2}{|c|}{ 1992-1995 } & \multicolumn{2}{|c|}{ 1996-1999 } & \multicolumn{2}{|c|}{ 2000-2003 } & \multicolumn{2}{|c|}{ 2004-2007 } & \multicolumn{2}{|c|}{ 2008-2011 } & \multicolumn{2}{|c|}{ 2012-2015 } & \multicolumn{2}{|c|}{ 2016-2019 } \\
\hline & (A) & $\%$ & $\begin{array}{c}R \\
\text { (A) }\end{array}$ & $\%$ & $\begin{array}{c}\mathbf{R} \\
\text { (A) }\end{array}$ & $\%$ & $\begin{array}{c}R \\
\text { (A) }\end{array}$ & $\%$ & $\begin{array}{c}R \\
\text { (A) }\end{array}$ & $\%$ & $\begin{array}{c}R \\
\text { (A) }\end{array}$ & $\%$ & $\begin{array}{c}R \\
\text { (A) }\end{array}$ & $\%$ & $\begin{array}{c}\mathrm{R} \\
\text { (A) }\end{array}$ & $\%$ & $\begin{array}{c}R \\
\text { (A) }\end{array}$ & $\%$ \\
\hline Sustainability & 864 & $45.2 \%$ & 0 & - & $28(1)$ & $50.0 \%$ & 6(5) & $13.2 \%$ & 1(39) & $46.4 \%$ & $2(47)$ & $34.8 \%$ & 1(154) & $49.5 \%$ & $2(206)$ & $31.2 \%$ & 1(412) & $18.2 \%$ \\
\hline Sustainable Development & 757 & $39.6 \%$ & 14(1) & $50.0 \%$ & 0 & - & $1(10)$ & $26.3 \%$ & $2(28)$ & $33.3 \%$ & $1(51)$ & $37.8 \%$ & 2(123) & $39.5 \%$ & $1(213)$ & $24.9 \%$ & 2(331) & $14.6 \%$ \\
\hline Environmental Management & 262 & $13.7 \%$ & $8(1)$ & $50.0 \%$ & $3(2)$ & $100.0 \%$ & $12(3)$ & $7.9 \%$ & $10(7)$ & $8.3 \%$ & 10(11) & $8.1 \%$ & $4(42)$ & $13.5 \%$ & $4(72)$ & $8.5 \%$ & $4(124)$ & $5.0 \%$ \\
\hline Decision Making & 235 & $12.3 \%$ & 0 & - & 0 & - & 0 & - & $7(8)$ & $9.5 \%$ & $11(10)$ & $7.4 \%$ & $6(35)$ & $11.3 \%$ & $8(52)$ & $7.1 \%$ & $3(130)$ & $4.1 \%$ \\
\hline Environmental Impact & 212 & $11.1 \%$ & 0 & - & 0 & - & 2(9) & $23.7 \%$ & $3(15)$ & $17.9 \%$ & $3(20)$ & $14.8 \%$ & $9(26)$ & $8.4 \%$ & $5(63)$ & $5.3 \%$ & $8(79)$ & $3.1 \%$ \\
\hline Environmental Sustainability & 182 & $9.5 \%$ & 0 & - & 0 & - & 0 & - & $33(4)$ & $4.8 \%$ & $18(7)$ & $5.2 \%$ & $11(22)$ & $7.1 \%$ & $7(53)$ & $4.5 \%$ & $7(96)$ & $2.6 \%$ \\
\hline Waste Management & 169 & $8.8 \%$ & 0 & - & 29(1) & $50.0 \%$ & $44(2)$ & $5.3 \%$ & $18(6)$ & $7.1 \%$ & $4(18)$ & $13.3 \%$ & $8(32)$ & $10.3 \%$ & $10(38)$ & $6.5 \%$ & $10(72)$ & $3.8 \%$ \\
\hline Supply Chain Management & 149 & $7.8 \%$ & 0 & - & 0 & - & 0 & - & 0 & - & 104(3) & $2.2 \%$ & $22(16)$ & $5.1 \%$ & $15(31)$ & $3.2 \%$ & $6(98)$ & $1.9 \%$ \\
\hline Life Cycle & 147 & $7.7 \%$ & 0 & - & 0 & - & 0 & - & $38(4)$ & $4.8 \%$ & $26(6)$ & $4.4 \%$ & $13(20)$ & $6.4 \%$ & $11(37)$ & $4.0 \%$ & $9(79)$ & $2.4 \%$ \\
\hline Construction Industry & 143 & $7.5 \%$ & 0 & - & 0 & - & $89(1)$ & $2.6 \%$ & $27(4)$ & $4.8 \%$ & $8(12)$ & $8.9 \%$ & $5(35)$ & $11.3 \%$ & $13(31)$ & $7.1 \%$ & $11(60)$ & $4.1 \%$ \\
\hline Industry & 132 & $6.9 \%$ & 0 & - & 0 & - & 0 & - & 6(9) & $10.7 \%$ & $36(5)$ & $3.7 \%$ & $7(33)$ & $10.6 \%$ & $6(60)$ & $6.7 \%$ & $48(24)$ & $3.9 \%$ \\
\hline Recycling & 132 & $6.9 \%$ & 0 & - & $19(1)$ & $50.0 \%$ & $5(5)$ & $13.2 \%$ & $41(4)$ & $4.8 \%$ & $7(13)$ & $9.6 \%$ & $10(25)$ & $8.0 \%$ & $19(27)$ & $5.1 \%$ & $13(57)$ & $3.0 \%$ \\
\hline Environmental Protection & 113 & $5.9 \%$ & 0 & - & 12(1) & $50.0 \%$ & $4(5)$ & $13.2 \%$ & $5(10)$ & $11.9 \%$ & $16(8)$ & $5.9 \%$ & $27(13)$ & $4.2 \%$ & $12(36)$ & $2.6 \%$ & $20(40)$ & $1.5 \%$ \\
\hline Water Manag & 108 & $5.7 \%$ & 0 & - & 0 & - & $47(2)$ & $5.3 \%$ & $13(7)$ & $8.3 \%$ & $67(4)$ & $3.0 \%$ & $15(19)$ & $6.1 \%$ & $9(39)$ & $3.8 \%$ & $25(37)$ & $2.2 \%$ \\
\hline Project Manage & 98 & $5.1 \%$ & 0 & - & 0 & - & 0 & - & 0 & - & $9(12)$ & $8.9 \%$ & $12(21)$ & $6.8 \%$ & $17(28)$ & $4.3 \%$ & $24(37)$ & $2.5 \%$ \\
\hline Priority Journal & 89 & $4.7 \%$ & 0 & - & 0 & - & 0 & - & $128(2)$ & $2.4 \%$ & $98(3)$ & $2.2 \%$ & 39(11) & $3.5 \%$ & $16(29)$ & $2.2 \%$ & $16(43)$ & $1.3 \%$ \\
\hline Innovation & 87 & $4.6 \%$ & 0 & - & 0 & - & 0 & - & 0 & - & $20(7)$ & $5.2 \%$ & $21(16)$ & $5.1 \%$ & $31(20)$ & $3.2 \%$ & $15(43)$ & $1.9 \%$ \\
\hline Economics & 83 & $4.3 \%$ & 0 & - & 0 & - & $3(5)$ & $13.2 \%$ & 20(5) & $6.0 \%$ & $81(3)$ & $2.2 \%$ & $36(11)$ & $3.5 \%$ & $18(27)$ & $2.2 \%$ & $29(32)$ & $1.3 \%$ \\
\hline Life Cycle Assessment & 83 & $4.3 \%$ & 0 & - & 0 & - & 0 & - & 111(2) & $2.4 \%$ & $54(4)$ & $3.0 \%$ & $50(10)$ & $3.2 \%$ & $27(21)$ & $2.0 \%$ & $14(45)$ & $1.2 \%$ \\
\hline Stakeholder & 80 & $4.2 \%$ & 0 & - & 0 & - & 0 & - & 0 & - & $21(7)$ & $5.2 \%$ & $18(17)$ & $5.5 \%$ & $20(26)$ & $3.4 \%$ & $39(29)$ & $2.0 \%$ \\
\hline
\end{tabular}

A: number of articles; R: rank position by number of articles in the four-year period; \%: percentage of articles in which it appears; (-): not data.

Figure 6 represents the keywords network map of the 1911 articles on the research topic. The keyword network maps is build up through the co-occurrences method and the different colors of nodes identify the clusters, while their size changes according to the keywords' frequency. We identify four main lines of research: "Environmental Protection", "Environmental Management", "Environmental Impact", and "Water Management" [35,39,64,74,125,126]. We set up this clusters according to the keywords associated to most articles in the sample, using the VOSviewer software.

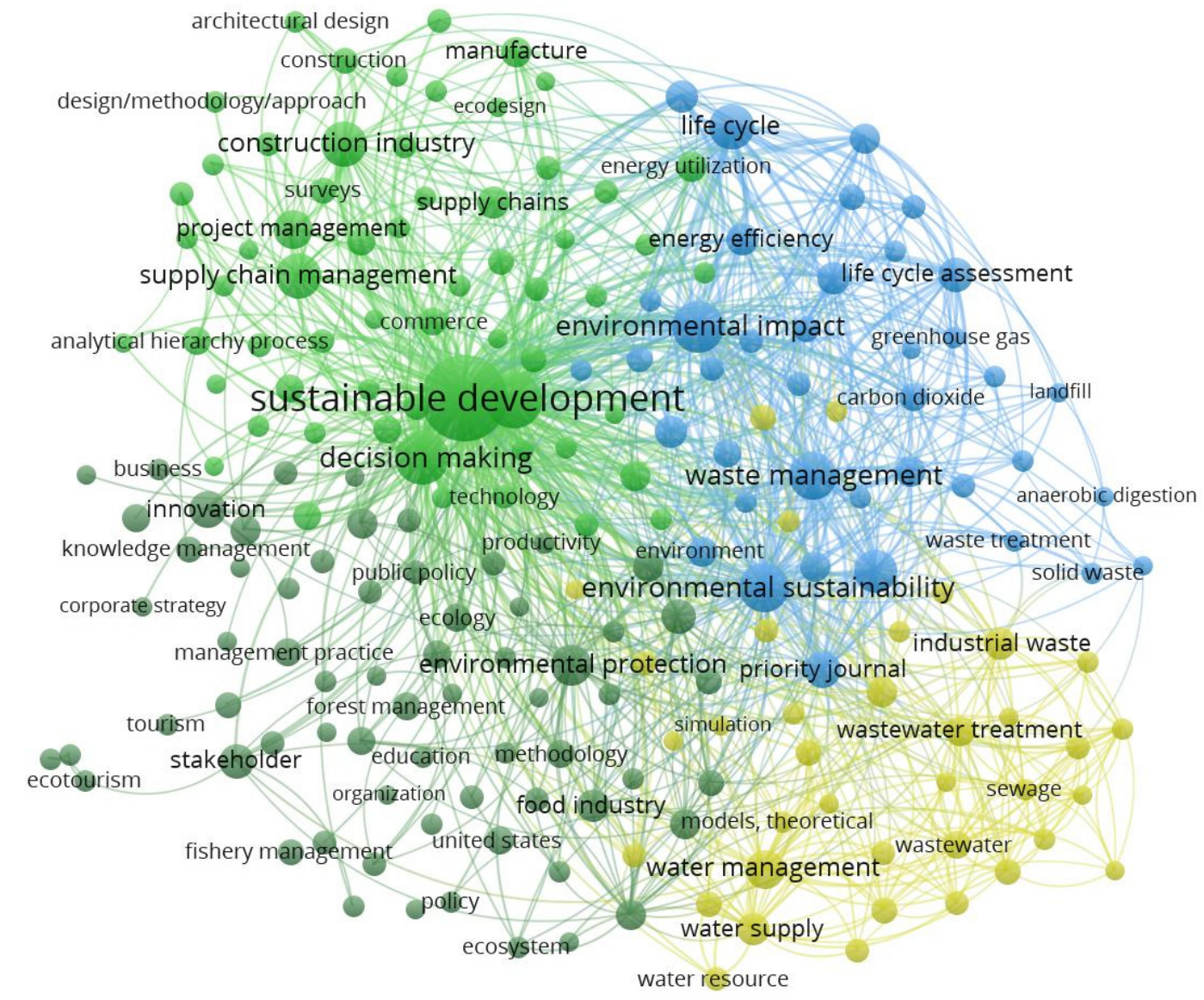

Figure 6. Keywords network map based on co-occurrence (1998-2019). 
Cluster 1 (grey) is about the thematic axe "Sustainability in processes". Cluster 1 is the bigger group and it has the $32 \%$ of the total keywords, Environmental Protection leads Cluster 1 with (113 articles) followed by Innovation (87 articles), Economics (83), Stakeholder (80), Food Industry (68), Economic and Social Effects (58), Agriculture (55), Environmental Economics (54), Conservation of Natural Resources (52), Forestry (45), Corporate Social Responsibility (44), Ecology (44), Forest Management (43), Implementation Process (39), Land Use (38), Governance Approach (33), Case Study (32), Public Policy (32), Strategic Approach (31), Strategic Planning (31), Biodiversity (30), Developing Countries (30), Industrial Ecology (30), Ecotourism (27), Education (27), Policy (26), Economic Aspect (25), or Ecosystem (25) among others.

We associate cluster 1 with the "Environmental protection" research line. This research line enables a political, economic, educational, and touristic approach. The political approach considers the relation to normative regulation; the economic one considers the costs and the consumption; the educational approach studies training at different academic levels; and the touristic approach considers tourism as an outstanding sector for a more sustainable society $[127,128]$.

Cluster 2 (green) is about the thematic axe "Environmental dimension of industry". Cluster 2 has the highest centrality and includes the 30\% of total keywords. Cluster 2 encompasses the keywords Environmental Management (262), Decision Making (235), Supply Chain Management (149), Construction Industry (143), Project Management (98), Supply Chains (62), Manufacture (60), Pollution Control (57), Energy Utilization (52), Analytical Hierarchy Process (51), Manufacturing (51), Risk Management (49), Commerce (46), Risk Assessment (44), Surveys (42), Decision Support Systems (39), Construction (37), Industrial Economics (36), Performance Assessment (36), Information Management (35), Sustainability Assessment (35), Sensitivity Analysis (34), Sustainable Supply Chains (34), Cleaner Production (33), Technology (33), Buildings (31), Quality Control (31), Environmental Technology (29), Hierarchical Systems (29), Product Design (29), Manufacturing Industries (28), Product Development (28), Costs (27), Industrial Management (27), Textile Industry (27), Environmental Regulations (26), Industrial Research (26), and Benchmarking (25).

We associate cluster 2 with the "Environmental management" research line. This research line studies the process that allows the reduction of environmental impacts and the efficiency progress to achieve economic, environmental, and operational improvements of organizations [129,130].

Cluster 3 (blue) is about the thematic axe "Industrial processes". Cluster 3 gathers 19\% of all keywords. It is associated with the following keywords: Environmental Sustainability (182), Waste Management (169), Life Cycle (147), Recycling (132), Life Cycle Assessment (83), Life Cycle Analysis (72), Environmental Performance (70), Climate Change (63), Wastewater Treatment (58), Life Cycle Assessment (LCA) (56), Environmental Impact Assessment (55), Waste Disposal (54), Environment (52), Carbon Dioxide (48), Optimization (44), Greenhouse Gases (37), Investments (37), Carbon Footprint (36), Emission Control (32), Biomass (31), Economic Analysis (31), Circular Economy (30), Global Warming (30), Carbon (27), Cost Benefit Analysis (27), Greenhouse Gas (27), Gas Emissions (26), Solid Waste (26), Biofuel (25), and Energy Management (25).

We associate cluster 3 with the "Environmental impact" research line. This research line studies the impact of industrial processes on the environment and its relationship with a more sustainable society. The scientific production of this thematic axis deals with the direct impact of the industry on nature, by the territorial development, the use of natural resources and waste production [131-134].

Finally, cluster 4 (yellow) is holds the "Industry" thematic axe. Cluster 4 is the smallest one, composed by $18 \%$ of keywords and head the "Water Management" research line. Cluster 4 is associated with the following keywords: Water Supply (71), Industrial Waste (62), Wastewater (45), Water Conservation (41), Waste Water Management (39), Water Resources (38), Energy Conservation (36), Water Quality (36), Chemical Industry (35), Water (32), Pollution (31), Water Resource (31), Water Pollution (30), Water Treatment (30), Waste Water (29), Sewage (28), Waste Treatment (27), Effluent (26), Effluents (25), and Energy (25). 
Water management is a research line that studies the sustainable water resources management and its effects on society. We define this research line as the effort to improve the understanding on how to promote a collaborative management of water, land, and resources, with the aim to maximize wellbeing and social justice, without compromising the sustainable functionality of ecosystems [135,136].

The four previous mentioned thematic axes encompass concepts related to the industrial processes management to achieve a more sustainable society, for example, sustainable development in globalized times and the causal effects of industrial management in society. There is a consolidation in the development of research that has led to an increase in the number of contributions, in relation to the implementation of management and implementation of sustainable policies in industrial processes. Similarly, there is an evolution in terminology that is accompanied by the emergence of new lines of research, such as those expressed below and in line with the results obtained $[137,138]$.

\subsection{Future Research Perspectives}

Figure 7 shows the changes over time and stability of each keyword network, because we can identify the time period in which they have been studied, according to the research sample observed in the 1988-2019 period.

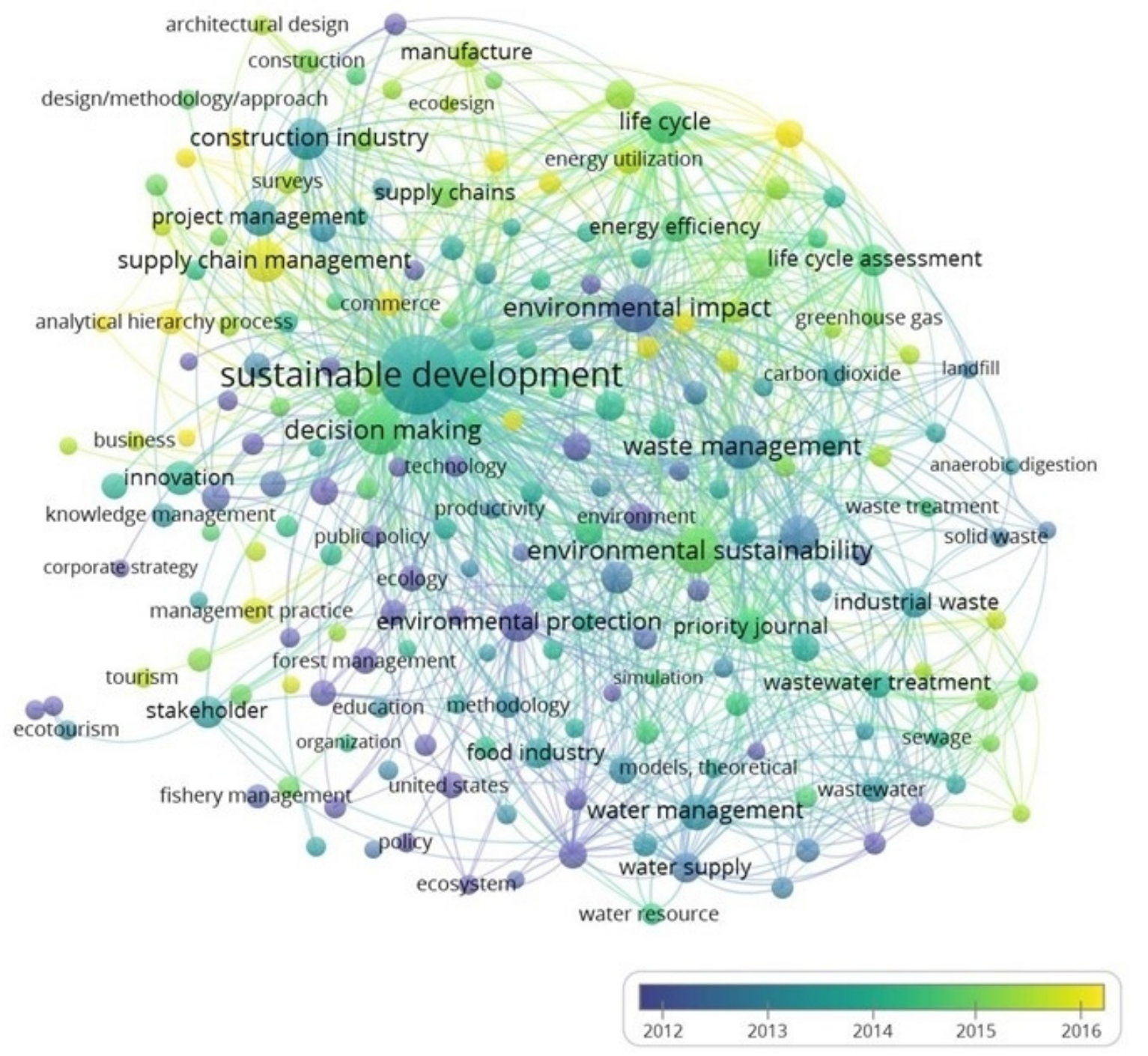

Figure 7. Evolution of keywords network map based on co-occurrence (1998-2019). 
We assume a significative increase in the keywords related to the research topic in the 2012-2015 period, influenced by the exponential increase in the articles publication on management of industrial processes for a more sustainable society. The keywords diversity in the bibliometric analysis brings out an idea of the range of researchs topics in the field of study. On the other hand, we also observe the emergence of another keywords group from 2016. The new keyword group encompass concepts like green cluster and environmental management to improve firms' environmental image and social responsibility coming from public authorities and civil society pressures.

Hence, Figure 7 let us to improve our understanding on the keywords relevance over time. So, the early bird keywords in the timeline have strong influence over the most recent keywords.

Research moves forward worldwide, incorporating new concepts and strategies that open new research lines. Indeed, we are witnessing the emergence of keywords such as social welfare, attracting consumer, or competitiveness that bridge the gap between Industry 4.0 and sustainability. The outcoming group of keywords pave the way for a new research line where the impact of Industry 4.0 on the triple bottom line will be explored $[139,140]$. The previous mentioned research line seeks to better understand how this dynamic relationship between economic development (job creation, cost reduction, and risk management); environmental responsibility (energy and resources conservation, renewable energy consumption, recycling, packaging reduction and decarbonization); and social welfare (working condition regulations, community enhancement, and the development of social responsibility in products and services).

On the other hand, we also identify controversial keywords related with the research topic in the analyzed literature, keywords like agrochemical, pesticide, tobacco, defense industry, bioengineering, robotics, or conflict mineral exploitation. These terms are connected to a new research line that adresses controversial issues at industries, provocative industries by its definition of international trade agreements, or by the unfair labor and wage conditions resulting from the high mobility of global capitals [141,142].

Moreover, we identify a concurrent research line that explores the regional and social perspectives of the "sin stock sectors". These sectors include the alcohol, tobacco, gambling, sex and firearms industry of which characteristics changes around the world. So, concerning this research line, the studies' interests turn around the behavior of ethical and socially responsible investments regarding ethically questionable activities, assuming the social benefit as the final goal $[143,144]$.

We recognize "the concept design of sustainable industrial process" as a new thematic axe encompassing keywords such as ecodesign, architectural design, or construction industry. Currently, a large number of companies include sustainable development within their commercial strategies, therefore industrial engineers seek to implement this strategy in the design of manufacturing process.

Likewise, artificial intelligence (AI) and sustainable development concepts set up the development of a new research line, aiming to understand how current technology will affect the planet through climate change and biodiversity loss. Therefore, previous research line studies how AI applications bring environmental benefits or not, considering tradeoffs, spillover, and rebound effects on water quality, air pollution, deforestation, soil quality degradation, and biodiversity $[145,146]$.

\section{Conclusions}

The aim of this study is to analyze the research trends of scientific production on industrial processes management for a more sustainable society, during the last 32 years. We drew up a bibliometric analysis of 1911 articles from the Elsevier Scopus database to depict the evolution of scientific production, thematic areas, journals, authors, institutions, the most productive countries, and the main research lines based on the keyword network analysis.

Scientific production increased every year during the 1988-2019 period, especially in the last period (2016-2019), where 845 documents have been published, accounting for the $44.2 \%$ of total articles.

We observe that most articles of our research topic are in the following four subject areas: Environmental Science; Business, Management and Accounting; Engineering; and Social Sciences. 
The outstanding diversity of subject areas in the articles sample demonstrates the cross-sectional approach of sustainability, which is linked with environmental, economic, social, scientific, and technological disciplines. Furthermore, the most productive journals are the Journal of Cleaner Production and Sustainability, together gathering $12.98 \%$ of total articles published. We observe that $75 \%$ of journals are in the first quartile of journals' ranking Scopus. The Journal of Cleaner Production is the most cited, and it has the highest h-index, but the International Journal of Production Economics has the highest average citations per article.

We notice that the $60 \%$ of authors are Europeans, therefore the most prolific authors, the most cited, and the author's with highest average citations per article belong to German research institutes.

The countries that publish the most in this research area are the United States and the United Kingdom, Australia, China, and Italy, with 50\% of the articles sample. Hong Kong has the highest percentage of international collaboration regarding articles' publication; even when this international exposition is not translated into higher citations rate, in comparison with the articles without international collaboration. The Netherlands and Italy are the only two countries that take advantage of the international co-authorship getting higher international citations.

In addition, we set up four thematic axes resulting from the industrial process management of industrial for a more sustainable society. The first thematic axis studies environmental protection, taking different approaches (political, economic, educational, or touristic); the second thematic axis addresses the environmental management; the third analyses the impact of environmental industrial processes on a more sustainable society; and, finally, the fourth thematic axis studies the sustainable management of water resources and its causal effects on society.

Likewise, we observed that the research field of industrial processes management for a sustainable society is gaining more attention from scholars and practitioners over the years. New research topics emerge, within the boundaries of interest of this study, to analyze the impact of Industry 4.0 on the sustainability triple bottom line. New research subjects address controversial issues at industries, provocative industries by its definition of international trade agreements, or by the unfair labor and wage conditions resulting from the high mobility of global capitals. Furthermore, we identify a concurrent research line that explores the behavior of ethical and socially responsible investments regarding non-ethical activities. On the other hand, new studies should address the concept design of sustainable industrial process, implemented in the manufacturing processes design. We identify the need for studies seeking to understand the relationship between artificial intelligence and sustainable development, to assess how current technological advances will affect the planet, due to challenges such as climate change and the loss of biodiversity.

Innovation in this research field has been identified based on the morphology of the clusters of authors, institutions, countries, and keywords, and the intensity of the relationships that develop in them. The results obtained are a complement to the area of knowledge of industrial processes and allow establishing the relationship between science and technology and supporting the decision-making process.

This study identifies some limitations that could be addresses in further research studies. In our study, the outcome is conditioned by the methodology we define, the database chosen, the keywords selected to extract the articles sample; the timeframe; and the analyzed variables. Therefore, the use of a different database and variables will bring out different outcomes, complementing the analysis and opening the floor for comparative studies.

Finally, we observed in the recent years that international research on industrial processes management for a more sustainable society shows an upward trend.

Author Contributions: Conceptualization, E.A.-S., M.E.M. and L.J.B.-U.; Investigation, E.A.-S., M.E.M. and L.J.B.U.; Methodology, M.E.M. and L.J.B.-U.; Resources, E.A.-S., M.E.M., F.J.C.-G. and L.J.B.-U.; Software, M.E.M. and L.J.B.-U.; Supervision, E.A.-S., M.E.M. and L.J.B.-U.; Validation, M.E.M., F.J.C.-G. and L.J.B.-U.; Writing-original draft, E.A.-S., M.E.M., F.J.C.-G. and L.J.B.-U.; Writing-review \& editing, E.A.-S., M.E.M. and L.J.B.-U; formal analysis, data curation, E.A.-S. and L.J.B.-U.; project administration, E.A.-S., M.E.M., F.J.C.-G. and L.J.B.-U.; funding acquisition, L.J.B.-U. All authors have read and agreed to the published version of the manuscript. 
Funding: This research received no external funding.

Conflicts of Interest: The authors declare no conflict of interest.

\section{References}

1. Swain, R.B.; Yang-Wallentin, F. Achieving sustainable development goals: Predicaments and strategies. Int. J. Sustain. Dev. World Ecology 2019, 27, 96-106. [CrossRef]

2. Xu, G. A Method of Establishing Process Specifications in Process Industry Based on Statistical Process Control. J. Mech. Eng. 2019, 55, 208. [CrossRef]

3. Xia, X.; Zhang, C. The Impact of Authorized Remanufacturing on Sustainable Remanufacturing. Processes 2019, 7, 663. [CrossRef]

4. Yao, T.; Huang, Z.; Zhao, W. Are smart cities more ecologically efficient? Evidence from China. Sustain. Cities Soc. 2020, 102008. [CrossRef]

5. Jacobides, M.G.; Kudina, A. How Industry Architectures Shape Firm Success when Expanding in Emerging Economies. Glob. Strategy J. 2013, 3, 150-170. [CrossRef]

6. Lee, S. Role of social and solidarity economy in localizing the sustainable development goals. International J. Sustain. Dev. World Ecology 2019, 27, 65-71. [CrossRef]

7. Vladimirova, K.; Le Blanc, D. Exploring Links between Education and Sustainable Development Goals Through the Lens of UN Flagship Reports. Sustain. Dev. 2016, 24, 254-271. [CrossRef]

8. Hickel, J. The contradiction of the sustainable development goals: Growth versus ecology on a finite planet. Sustain. Dev. 2019, 27, 873-884. [CrossRef]

9. Gude, V.G. Sustainable chemistry and chemical processes for a sustainable future. Resour. Effic. Technol. 2017, 3, 249-251. [CrossRef]

10. Lanciano, E.; Saleilles, S. Small firms in the sustainable transformation of food industry: Entangling entrepreneurship and activism in grassroots innovation processes. Sociol. DEL Lav. 2017, 147, 111-127. [CrossRef]

11. Kyzas, G.; Matis, K. The Flotation Process Can Go Green. Processes 2019, 7, 138. [CrossRef]

12. Torres, J.; Valera, D.L.; Belmonte, L.J.; Herrero-Sánchez, C. Economic and social sustainability through organic agriculture: Study of the restructuring of the citrus sector in the "bajo andarax" district (Spain). Sustainability 2016, 8, 918. [CrossRef]

13. Humphries, J.; Schneider, B. Spinning the industrial revolution. Econ. Hist. Rev. 2018, 72, 126-155. [CrossRef]

14. Greasley, D.; Oxley, L. Causality and the First Industrial Revolution. Ind. Corp. Chang. 1988, 7, $33-47$. [CrossRef]

15. Boyer, G.R.; Mokyr, J. The Economics of the Industrial Revolution. Ind. Labor Relat. Rev. 1986, $39,604$. [CrossRef]

16. Landsberger, H.A.; Hartwell, R.M. The Industrial Revolution. Soc. Forces 1974, 53, 144. [CrossRef]

17. Jackson, R.V. Rates of Industrial Growth during the Industrial Revolution. Econ. Hist. Rev. 1992, 45, 1. [CrossRef]

18. Loureiro, A. There is a fourth industrial revolution: The digital revolution. Worldw. Hosp. Tour. Themes 2018, 10, 740-744. [CrossRef]

19. Rhyne, E.; Otero, M. Microfinance Matures: Opportunities, Risks, and Obstacles for an Emerging Global Industry. Innov. Technol. Gov. Glob. 2007, 2, 91-114. [CrossRef]

20. Darkow, I.-L.; Von Der Gracht, H.A. Scenarios for the future of the European process industry - the case of the chemical industry. Eur. J. Futures Res. 2013, 1. [CrossRef]

21. Jänicke, M. "Green growth": From a growing eco-industry to economic sustainability. Energy Policy 2012, 48, 13-21. [CrossRef]

22. Hmaittane, A.; Bouslah, K.; M'Zali, B. Does corporate social responsibility affect the cost of equity in controversial industry sectors? Rev. Account. Financ. 2019, 18, 635-662. [CrossRef]

23. O'Riordan, T.J.C. UN sustainable development goals: How can sustainable/green chemistry contribute? The view from the agrochemical industry. Curr. Opin. Green Sustain. Chem. 2018, 13, 172-173. [CrossRef]

24. Kostygova, L.A. Sustainable Development Titanium Industry. Econ. Ind. 2015, 4, 20. [CrossRef]

25. Patel, D.; Kellici, S.; Saha, B. Green Process Engineering as the Key to Future Processes. Processes 2014, 2, 311-332. [CrossRef] 
26. Ferto, I.; Soós, K.A. Controversial issues in factors determining intra-industry trade. Int. J. Econ. Bus. Res. 2012, 4, 132. [CrossRef]

27. Potgieter, J.H. An Overview of Cement production: How "green" and sustainable is the industry? Environ. Manag. Sustain. Dev. 2012, 1. [CrossRef]

28. Luken, R.A. Where is developing country industry in sustainable development planning? Sustain. Dev. 2006, 14, 46-61. [CrossRef]

29. Venables, M. Striving for process excellence [process industry]. Manuf. Eng. 2004, 83, 40-43. [CrossRef]

30. Stigson, B. Sustainable development for industry and society. Build. Res. Inf. 1999, 27, 424-430. [CrossRef]

31. Szekely, J.; Laudise, R. Green materials and green processes. J. Mater. Res. 1995, 10, 485-486. [CrossRef]

32. Freeman, R.E.; Phillips, R.A. Stakeholder Theory: A Libertarian Defense. Bus. Ethics Q. 2002, 12, 331-349. [CrossRef]

33. Smith, P.A. Stakeholder Engagement Framework. Inf. Secur. Int. J. 2017, 38, 35-45. [CrossRef]

34. Schaltegger, S.; Hörisch, J.; Freeman, R.E. Business Cases for Sustainability: A Stakeholder Theory Perspective. Organ. Environ. 2017, 32, 191-212. [CrossRef]

35. Plaza Úbeda, J.A.; Jiménez, J.D.B.; Belmonte-Ureña, L.J. Stakeholders, environmental management and performance: An integrated approach. Cuad. De Econ. Y Dir. De La Empresa 2011, 14, 151-161. [CrossRef]

36. Cots, E.G. Stakeholder social capital: A new approach to stakeholder theory. Bus. Ethics A Eur. Rev. 2011, 20, 328-341. [CrossRef]

37. Freeman, E.; Moutchnik, A. Stakeholder management and CSR: Questions and answers. Uwf Umw. 2013, 21, 5-9. [CrossRef]

38. Al-Kassem, A.H. Recruitment and Selection Practices in Business Process Outsourcing Industry. Arch. Bus. Res. 2017, 5. [CrossRef]

39. Styhre, A.; Ingelgård, A.; Roth, J. Gendering knowledge: The practices of knowledge management in the pharmaceutical industry. Knowl. Process. Manag. 2001, 8, 65-74. [CrossRef]

40. Plaut, J. Industry environmental processes: Beyond compliance. Technol. Soc. 1998, 20, 469-479. [CrossRef]

41. Canabarro, N.; Soares, J.F.; Anchieta, C.G.; Kelling, C.S.; Mazutti, M.A. Thermochemical processes for biofuels production from biomass. Sustain. Chem. Process. 2013, 1, 22. [CrossRef]

42. Roddeck, W. Automation in forming processes. Comput. Ind. 1979, 1, 111-116. [CrossRef]

43. Rosenthal, K.; Lütz, S. Recent developments and challenges of biocatalytic processes in the pharmaceutical industry. Curr. Opin. Green Sustain. Chem. 2018, 11, 58-64. [CrossRef]

44. Sahu, O.; Rao, D.G.; Thangavel, A.; Ponnappan, S. Treatment of sugar industry wastewater using a combination of thermal and electrocoagulation processes. Int. J. Sustain. Eng. 2017, 11, 16-25. [CrossRef]

45. Huang, Y.; Fan, L. Artificial intelligence for waste minimization in the process industry. Comput. Ind. 1993, 22, 117-128. [CrossRef]

46. Leppänen, P.; Kraslawski, A.; Avramenko, Y. Innovation in Organization of Design Process in Pulp and Paper Industry Projects. Knowl. Process. Manag. 2011, 18, 133-149. [CrossRef]

47. Zhang, L.; Wang, J.; Wen, H.; Fu, Z.; Li, X. Operating performance, industry agglomeration and its spatial characteristics of Chinese photovoltaic industry. Renew. Sustain. Energy Rev. 2016, 65, 373-386. [CrossRef]

48. McManus, P. Defining sustainable development for our common future: A history of the World Commission on Environment and Development (Brundtland Commission). Aust. Geogr. 2014, 45, 559-561. [CrossRef]

49. Holden, E.; Linnerud, K.; Banister, D. The Imperatives of Sustainable Development. Sustain. Dev. 2016, 25, 213-226. [CrossRef]

50. Brundtland, G.H. World summit on sustainable development. BMJ 2002, 325, 399-400. [CrossRef]

51. Holden, E.; Linnerud, K.; Banister, D. Sustainable development: Our Common Future revisited. Global Environ. Chang. 2014, 26, 130-139. [CrossRef]

52. Dalampira, E.; Nastis, S.A. Mapping Sustainable Development Goals: A network analysis framework. Sustain. Dev. 2019, 28, 46-55. [CrossRef]

53. Wysokińska, Z. Millenium Development Goals/UN and Sustainable Development Goals/UN as Instruments for Realising Sustainable Development Concept in the Global Economy. Comp. Econ. Res. 2017, 20, 101-118. [CrossRef]

54. Fedulova, L. Development trends and implementation of digital technologies for sustainable development goals. Environ. Econ. Sustain. Dev. 2020, 7, 6-14. [CrossRef] 
55. Rosen, M.A. How Can We Achieve the UN Sustainable Development Goals? Eur. J. Sustain. Dev. Res. 2017, 1, 1-4. [CrossRef]

56. Haliscelik, E.; Soytaş, M.A. Sustainable development from millennium 2015 to Sustainable Development Goals 2030. Sustain. Dev. 2019, 27, 545-572. [CrossRef]

57. Luken, R.; Mörec, U.; Meinert, T. Data quality and feasibility issues with industry-related Sustainable Development Goal targets for Sub-Saharan African countries. Sustain. Dev. 2019, 28, 91-100. [CrossRef]

58. Kopnina, H. The victims of unsustainability: A challenge to sustainable development goals. Int. J. Sustain. Dev. World Ecol. 2015, 23, 113-121. [CrossRef]

59. Zhu, P. Studies on Sustainable Development of Ecological Sports Tourism Resources and Its Industry. J. Sustain. Dev. 2009, 2. [CrossRef]

60. Jones, P.; Comfort, D. Sustainability and the UK Waste Management Industry. Eur. J. Sustain. Dev. Res. 2018, 2. [CrossRef]

61. Vivoda, V.; Kemp, D. How do national mining industry associations compare on sustainable development? Extr. Ind. Soc. 2019, 6, 22-28. [CrossRef]

62. Williams, S.; Robinson, J. Measuring sustainability: An evaluation framework for sustainability transition experiments. Environ. Sci. Policy 2020, 103, 58-66. [CrossRef]

63. Henriques, M.H.; Brilha, J.B. UNESCO Global Geoparks: A strategy towards global understanding and sustainability. Episodes 2017, 40, 349-355. [CrossRef]

64. Paskova, M.; Zelenka, J. Sustainability Management of Unesco Global Geoparks. Sustain. Geosci. Geotourism 2018, 2, 44-64. [CrossRef]

65. Agbedahin, A. Sustainable development, Education for Sustainable Development, and the 2030 Agenda for Sustainable Development: Emergence, efficacy, eminence, and future. Sustain. Dev. 2019, 27, 669-680. [CrossRef]

66. Bapat, S.S.; Aichele, C.P.; A High, K. Development of a sustainable process for the production of polymer grade lactic acid. Sustain. Chem. Process. 2014, 2, 3. [CrossRef]

67. E Watanabe, M. The United Nations Sustainable Development Goals. BioScience 2020, 70, 205-212. [CrossRef]

68. Alawneh, R.; Ghazali, F.E.M.; Ali, H.; Sadullah, A.F. A Novel framework for integrating United Nations Sustainable Development Goals into sustainable non-residential building assessment and management in Jordan. Sustain. Cities Soc. 2019, 49, 101612. [CrossRef]

69. Lee, K.H.; Noh, J.; Khim, J.S. The Blue Economy and the United Nations' sustainable development goals: Challenges and opportunities. Environ. Int. 2020, 137, 105528. [CrossRef]

70. Balta, M.T.; Dincer, I.; Hepbasli, A. Development of sustainable energy options for buildings in a sustainable society. Sustain. Cities Soc. 2011, 1, 72-80. [CrossRef]

71. Deakin, M.; Reid, A. Sustainable urban development: Use of the environmental assessment methods. Sustain. Cities Soc. 2014, 10, 39-48. [CrossRef]

72. Naganathan, H.; Chong, W.K. Evaluation of state sustainable transportation performances (SSTP) using sustainable indicators. Sustain. Cities Soc. 2017, 35, 799-815. [CrossRef]

73. Atanda, J. Developing a social sustainability assessment framework. Sustain. Cities Soc. 2019, 44, $237-252$. [CrossRef]

74. Singla, L.; Vashist, S. Efficient Workload Management in Cloud Computing. Int. J. Sci. Res. 2012, 3, $154-157$. [CrossRef]

75. Shavkun, I.; Dybchinska, Y. Efficient manager: Creative dimension. Manag. Entrep. Trends Dev. 2019, 2, 47-59. [CrossRef]

76. Baldenius, T.; Reichelstein, S. Incentives for Efficient Inventory Management: The Role of Historical Cost. Manag. Sci. 2005, 51, 1032-1045. [CrossRef]

77. Garcia-Verdugo, E.; Altava, B.; Burguete, M.I.; Lozano, P.; Luis, S.V. Ionic liquids and continuous flow processes: A good marriage to design sustainable processes. Green Chem. 2015, 17, 2693-2713. [CrossRef]

78. Keane, M.A. Advances in greener separation processes? Case study: Recovery of chlorinated aromatic compounds. Green Chem. 2003, 5, 309. [CrossRef]

79. Salimova, T.; Guskova, N.; Krakovskaya, I.; Sirota, E. From industry 4.0 to Society 5.0: Challenges for sustainable competitiveness of Russian industry. IOP Conf. Series: Mater. Sci. Eng. 2019, 497, 012090. [CrossRef] 
80. Valera, D.L.; Belmonte, L.J.; Molina-Aiz, F.D.; López, A.; Camacho, F. The greenhouses of Almería, Spain: Technological analysis and profitability. Acta Hortic. 2017, 1170, 219-226. [CrossRef]

81. Makris, D.P. Green extraction processes for the efficient recovery of bioactive polyphenols from wine industry solid wastes - Recent progress. Curr. Opin. Green Sustain. Chem. 2018, 13, 50-55. [CrossRef]

82. Khalil, M.E. Exploring Inclusiveness in Green Hotels for Sustainable Development in Egypt. Int. J. Ind. Sustain. Dev. 2020, 1, 15-23. [CrossRef]

83. Guo, J.; Mao, H.; Wang, T. Ecological Industry: A Sustainable Economy Developing Pattern. J. Sustain. Dev. 2010, 3. [CrossRef]

84. Chen, C.-W. Improving Circular Economy Business Models: Opportunities for Business and Innovation: A new framework for businesses to create a truly circular economy. Johns. Matthey Technol. Rev. 2020, 64, 48-58. [CrossRef]

85. Olabi, A.G. Circular economy and renewable energy. Energy 2019, 181, 450-454. [CrossRef]

86. Bolger, K.; Doyon, A. Circular cities: Exploring local government strategies to facilitate a circular economy. Eur. Plan. Stud. 2019, 27, 2184-2205. [CrossRef]

87. ISO 26000 and SDGS. Available online: https://www.iso.org/publication/PUB100401.html (accessed on 2 May 2020).

88. Hahn, R. ISO 26000 and the Standardization of Strategic Management Processes for Sustainability and Corporate Social Responsibility. Bus. Strat. Environ. 2012, 22, 442-455. [CrossRef]

89. ISO 26000:2010. Available online: https://www.iso.org/iso-26000-social-responsibility.html (accessed on 3 May 2020).

90. Price, D.D.S. The analysis of scientometric matrices for policy implications. Scientometrics 1981, 3, 47-53. [CrossRef]

91. Garfield, E. Derek Price and the Practical World of Scientometrics. Sci. Technol. Hum. Values 1988, 13, 349-350. [CrossRef]

92. Prathap, G. Eugene Garfield: From the metrics of science to the science of metrics. Scientometrics 2017, 114, 637-650. [CrossRef]

93. Abad-Segura, E.; González-Zamar, M.-D. Global Research Trends in Financial Transactions. Mathematics 2020, 8, 614. [CrossRef]

94. González-Zamar, M.-D.; Jiménez, L.O.; Ayala, A.S.; Abad-Segura, E. The Impact of the University Classroom on Managing the Socio-Educational Well-being: A Global Study. Int. J. Environ. Res. Public Heal. 2020, 17, 931. [CrossRef] [PubMed]

95. Belmonte-Ureña, L.J.; Garrido-Cardenas, J.A.; Camacho-Ferre, F. Analysis of World Research on Grafting in Horticultural Plants. HortScience 2020, 55, 112-120. [CrossRef]

96. Abad-Segura, E.; González-Zamar, M.-D.; Infante-Moro, J.C.; Ruipérez García, G. Sustainable Management of Digital Transformation in Higher Education: Global Research Trends. Sustainability 2020, 12, 2107. [CrossRef]

97. Duque-Acevedo, M.; Belmonte-Ureña, L.J.; Cortés-García, F.J.; Camacho-Ferre, F. Agricultural waste: Review of the evolution, approaches and perspectives on alternative uses. Glob. Ecol. Conserv. 2020, 22. [CrossRef]

98. Abad-Segura, E.; Cortés-García, F.J.; Belmonte-Ureña, L.J. The sustainable approach to corporate social responsibility: A global analysis and future trends. Sustainability 2019, 11, 5382. [CrossRef]

99. Leydesdorff, L.; Van Den Besselaar, P. Scientometrics and communication theory: Towards theoretically informed indicators. Scientometrics 1997, 38, 155-174. [CrossRef]

100. Abad-Segura, E.; González-Zamar, M.D. Effects of Financial Education and Financial Literacy on Creative Entrepreneurship: A Worldwide Research. Educ. Sci. 2019, 9, 238. [CrossRef]

101. Prathap, G. Quantity, quality, and consistency as bibliometric indicators. J. Assoc. Inf. Sci. Technol. 2013, 65, 214. [CrossRef]

102. Su, H.-N.; Lee, P.-C. Mapping knowledge structure by keyword co-occurrence: A first look at journal papers in Technology Foresight. Scientometrics 2010, 85, 65-79. [CrossRef]

103. Lee, C.I.S.; Felps, W.; Baruch, Y. Mapping Career Studies: A Bibliometric Analysis. Acad. Manag. Proc. 2014, 2014, 14214. [CrossRef]

104. Ponomariov, B.; Boardman, C. What is co-authorship? Scientometrics 2016, 109, 1939-1963. [CrossRef]

105. Van Eck, N.J.; Waltman, L. Software survey: VOSviewer, a computer program for bibliometric mapping. Scientometrics 2009, 84, 523-538. [CrossRef] [PubMed] 
106. Van Eck, N.J.; Waltman, L.; Noyons, E.C.M.; Buter, R.K. Automatic term identification for bibliometric mapping. Scientometrics 2010, 82, 581-596. [CrossRef] [PubMed]

107. Fontana, L.B.; Oldekop, J.A. The sustainable development goals: The bumpy road ahead. World Dev. 2020, 127, 104770. [CrossRef]

108. Dang, H.-A.H.; Serajuddin, U. Tracking the sustainable development goals: Emerging measurement challenges and further reflections. World Dev. 2020, 127, 104570. [CrossRef]

109. Buckley, P.J.; Pass, C.L.; Prescott, K. Measures of international competitiveness: A critical survey. J. Mark. Manag. 1988, 4, 175-200. [CrossRef]

110. White, H.D. Co-cited author retrieval and relevance theory: Examples from the humanities. Scientometrics 2014, 102, 2275-2299. [CrossRef]

111. Strobl, A.; Bauer, F.; Matzler, K. The impact of industry-wide and target market environmental hostility on entrepreneurial leadership in mergers and acquisitions. J. World Bus. 2020, 55, 100931. [CrossRef]

112. Li, Y.; Xu, L.; Sun, T.; Ding, R. The impact of project environmental practices on environmental and organizational performance in the construction industry. Int. J. Manag. Proj. Bus. 2019, 13, 367-387. [CrossRef]

113. Strunz, S.; Marselle, M.; Schröter, M. Leaving the "sustainability or collapse" narrative behind. Sustain. Sci. 2019, 14, 1717-1728. [CrossRef]

114. Wright, P.M.; Nyberg, A.J. Academic research meets practice: Why controversial results are not controversial. Manag. Res. J. Iberoam. Acad. Manag. 2018, 16, 66-74. [CrossRef]

115. Vachon, S.; Klassen, R. Environmental management and manufacturing performance: The role of collaboration in the supply chain. Int. J. Prod. Econ. 2008, 111, 299-315. [CrossRef]

116. Dragos, C.M.; Dragos, S.L. Bibliometric approach of factors affecting scientific productivity in environmental sciences and ecology. Sci. Total. Environ. 2013, 449, 184-188. [CrossRef] [PubMed]

117. Zhuchenko, O. Control system of carbon production. Sci. Notes Taurida Natl. V.I. Vernadsky Univ. Series Tech. Sci. 2020, 1, 72-78. [CrossRef]

118. Feinstein, N.W.; Kirchgasler, K. Sustainability in Science Education? How the Next Generation Science Standards Approach Sustainability, and Why It Matters. Sci. Educ. 2014, 99, 121-144. [CrossRef]

119. Pauliuk, S. Making sustainability science a cumulative effort. Nat. Sustain. 2019, 3, 2-4. [CrossRef]

120. Robinson-Garcia, N.; Sugimoto, C.R.; Murray, D.; Yegros-Yegros, A.; Larivière, V.; Costas, R. The many faces of mobility: Using bibliometric data to measure the movement of scientists. J. Inf. 2019, 13, 50-63. [CrossRef]

121. Checchi, D.; Malgarini, M.; Sarlo, S. Do performance-based research funding systems affect research production and impact? High. Educ. Q. 2018, 73, 45-69. [CrossRef]

122. Freeth, R.; Caniglia, G. Learning to collaborate while collaborating: Advancing interdisciplinary sustainability research. Sustain. Sci. 2019, 15, 247-261. [CrossRef]

123. Van Eck, N.J.; Waltman, L. Citation-based clustering of publications using CitNetExplorer and VOSviewer. Scientometrics 2017, 111, 1053-1070. [CrossRef] [PubMed]

124. Campbell, M.C. Sustainable economic growth and environmental conservation. Environ. Pr. 2018, $20,1-2$. [CrossRef]

125. Paulsson, A. Making the sustainable more sustainable: Public transport and the collaborative spaces of policy translation. J. Environ. Policy Plan. 2018, 20, 419-433. [CrossRef]

126. Nakic, D. Environmental evaluation of concrete with sewage sludge ash based on LCA. Sustain. Prod. Consum. 2018, 16, 193-201. [CrossRef]

127. Arora, N.K. Biodiversity conservation for sustainable future. Environ. Sustain. 2018, 1, 109-111. [CrossRef]

128. Ellerbrock, M.J. Sustainable development requires environmental justice. Int. J. Sustain. Dev. Plan. 2018, 13, 208-214. [CrossRef]

129. Kakouris, A.; Sfakianaki, E. Motives for implementing ISO 9000 - does enterprise size matter? Int. J. Prod. Perform. Manag. 2019, 68, 447-463. [CrossRef]

130. Zeiger, B.; Gunton, T.; Rutherford, M. Toward sustainable development: A methodology for evaluating environmental planning systems. Sustain. Dev. 2018, 27, 13-24. [CrossRef]

131. Schlosberg, D. From postmaterialism to sustainable materialism: The environmental politics of practice-based movements. Environ. Politi. 2019, 1-21. [CrossRef]

132. Berawi, M.A. The Role of Industry 4.0 in Achieving Sustainable Development Goals. Int. J. Technol. 2019, 10, 644. [CrossRef] 
133. De Gooyert, V. Long term investments in critical infrastructure under environmental turbulence; Dilemmas of infrastructure responsiveness. Sustain. Futur. 2020, 2, 100028. [CrossRef]

134. Mersal, A. Sustainable Urban Futures: Environmental Planning for Sustainable Urban Development. Procedia Environ. Sci. 2016, 34, 49-61. [CrossRef]

135. Mathews, R. A Six-Step Framework for Ecologically Sustainable Water Management. J. Contemp. Water Res. Educ. 2009, 131, 60-65. [CrossRef]

136. Belmonte-Ureña, L.J.; Román-Sánchez, I.M. Appraisal of environmental regulations on sustainable consumption of water in the wine-producing spanish industry. Environ. Eng. Manag. J. 2013, 12, 1979-1987. [CrossRef]

137. Adam, I.H.D.; Jusoh, A.; Mardani, A.; Streimikiene, D.; Nor, K.M. Scoping research on sustainability performance from manufacturing industry sector. Probl. Perspect. Manag. 2019, 17, 134-146. [CrossRef]

138. Krdžalić, A.; Hodžić, L. Sustainable engineering challenges towards Industry 4.0: A comprehensive review. Sustain. Eng. Innov. ISSN 2712-0562 2019, 1, 1-23. [CrossRef]

139. Jena, M.C.; Mishra, S.K.; Moharana, H.S. Application of Industry 4.0 to enhance sustainable manufacturing. Environ. Prog. Sustain. Energy 2019, 39, 13360. [CrossRef]

140. Miranda, J.; Ponce, P.; Molina, A.; Wright, P. Sensing, smart and sustainable technologies for Agri-Food 4.0. Computers in Industry 2019, 108, 21-36. [CrossRef]

141. Fatma, M.; Khan, I.; Rahman, Z. Striving for legitimacy through CSR: An exploration of employees responses in controversial industry sector. Soc. Responsib. J. 2019, 15, 924-938. [CrossRef]

142. Song, B.; Wen, J.; Ferguson, M.A. Toward effective CSR communication in controversial industry sectors. J. Mark. Commun. 2018, 26, 243-267. [CrossRef]

143. Lovrinčević, Ž.; Mikulić, D.; Orlović, A. Economic Aspects of Sin Industry in Croatia. Drustvena Istraz. 2015, 24, 175-196. [CrossRef]

144. Malone, R.E. "Sustainable" tobacco industry? Tob. Control. 2019, 28, e85. [CrossRef] [PubMed]

145. Miller, T. Explanation in artificial intelligence: Insights from the social sciences. Artif. Intell. 2019, $267,1-38$. [CrossRef]

146. Sharma, G.D.; Yadav, A.; Chopra, R. Artificial intelligence and effective governance: A review, critique and research agenda. Sustain. Futures 2020, 2, 100004. [CrossRef]

(C) 2020 by the authors. Licensee MDPI, Basel, Switzerland. This article is an open access article distributed under the terms and conditions of the Creative Commons Attribution (CC BY) license (http://creativecommons.org/licenses/by/4.0/). 